\title{
Deciphering the roles of IncRNAs in breast development and disease
}

\author{
John Lalith Charles Richard ${ }^{1,2,4}$ and Pieter Johan Adam Eichhorn ${ }^{1,2,3}$ \\ ${ }^{1}$ Cancer Science Institute of Singapore, National University of Singapore, 117599, Singapore \\ ${ }^{2}$ Department of Pharmacology, Yong Loo Lin School of Medicine, National University of Singapore, 117597, Singapore \\ ${ }^{3}$ School of Pharmacy, Curtin University, Perth, 6845, Australia \\ ${ }^{4}$ Current Address: Genome Institute of Singapore, Agency for Science Technology and Research, 138672, Singapore \\ Correspondence to: Pieter Johan Adam Eichhorn, email: pieter_eichhorn@nus.edu.sg \\ Keywords: long non-coding RNA; breast cancer; mammary gland development; XIST; HOTAIR \\ Received: July 29, 2017 Accepted: February 21,2018 Epub: February 28, 2018 Published: April 13, 2018
}

Copyright: Charles Richard et al. This is an open-access article distributed under the terms of the Creative Commons Attribution License 3.0 (CC BY 3.0), which permits unrestricted use, distribution, and reproduction in any medium, provided the original author and source are credited.

\section{ABSTRACT}

Breast cancer is the second leading cause of cancer related deaths in women. It is therefore important to understand the mechanisms underlying breast cancer development as well as raises the need for enhanced, non-invasive strategies for novel prognostic and diagnostic methods. The emergence of long non-coding RNAs (IncRNAs) as potential key players in neoplastic disease has received considerable attention over the past few years. This relatively new class of molecular regulators has been shown from ongoing research to act as critical players for key biological processes. Deregulated expression levels of IncRNAs have been observed in a number of cancers including breast cancer. Furthermore, IncRNAs have been linked to breast cancer initiation, progression, metastases and to limit sensitivity to certain targeted therapeutics. In this review we provide an update on the IncRNAs associated with breast cancer and mammary gland development and illustrate the versatility of such IncRNAs in gene control, differentiation and development both in normal physiological conditions and in diseased states. We also highlight the therapeutic and diagnostic potential of IncRNAs in cancer.

\section{INTRODUCTION}

Breast cancer poses a major public health concern with breast cancer being not only the most common cancer in women but, also the second leading cause of cancer related deaths in women worldwide [1]. Even with the incredible recent surge in diagnostics and drug discovery, resistance to cancer treatments remains an altogether substantial issue [2]. Innumerable mutations and copy number changes in tumor suppressors and oncogenes have been implicated in breast cancer development leading to a cascade of events enhancing mammary cell proliferation, abnormal differentiation and enhanced migration and invasion $[3,4]$. However, in a large subset of cancers the causal agents of breast cancer remain obscure. Interestingly, even though the mammary gland itself is unimportant for the maintenance of life, the onset of breast cancer can be fatal if the disease manifests and metastasis ensues. During mammary gland development from embryogenesis through puberty, pregnancy, lactation and involution, the mammary gland undergoes a series of morphogenetic cues arising from a complex crosstalk of molecular factors effecting dramatic anatomical and physiological changes in the gland [5-7]. Interestingly, the genetic factors required for the organization of this complex framework have also been demonstrated to be mutated in breast cancer.

The advent of sequencing technologies has enabled intense whole genome transcriptome analysis possible and our understanding of the components that make up our complex genome has been revamped [8-10]. Not too long ago the majority of the transcriptome realm was still 
considered "junk" because large parts of the DNA did not appear to transcribe functional proteins. However, recently these vast stretches of the genome have been annotated and discovered to contain thousands of non-coding RNA (ncRNA). Unexpectedly, ncRNA and its various species are more abundant than protein coding genes. Today, thousands of these ncRNA have been reported and catalogued, thanks to huge genomics initiatives like ENCODE (Encyclopedia of DNA Elements), FANTOM (Functional Annotation of Mouse Genome), GTEx (Genotype-Tissue Expression) and GENCODE, the field of ncRNA research has exploded [11-14]. Furthermore, exploration into the roles of ncRNA has vastly enhanced our understanding of human diseases including the pathophysiology of breast cancer $[15,16]$.

Non-coding RNAs are divided into two broad classes based on their functions, as housekeeping and regulatory. While, housekeeping ncRNAs are constitutively expressed and are particularly involved in the operation of vital cellular functions, regulatory ncRNAs are expressed in a developmental and tissue specific manner or may be altered in certain disease conditions. Some of the ncRNAs that fall under the housekeeping ncRNAs are ribosomal RNA (rRNA), transfer RNA (tRNA), small nuclear RNA (snRNA) and small nucleolar RNA (snoRNA). Additionally, regulatory ncRNA are broadly classified into two classes as short non-coding transcripts or long non-coding. Examples of short non-coding RNAs include microRNA (miRNA), small interfering RNA (siRNA), piwi interacting RNA (piRNA), among others [17-21]. Like short ncRNA, lncRNA has been demonstrated to play important roles in numerous diseases including cancer [22-25]. However, to date only but a small fraction of the lncRNAs have been functionally characterized, leaving us to ponder over the biological functions of those remaining and the crucial roles they might play. LncRNAs have been implicated in many biological processes like dosage compensation, imprinting, cell cycle regulation, retro-transposon silencing, pluripotency and telomere lengthening just to name a few. They further employ diverse molecular mechanisms to carry out multiple functions [26-29]. While some lncRNAs are involved in the regulation of genes through their interaction at the transcription site, others behave as molecular decoys, trapping transcription factors, diverting the association with DNA transcription factor binding sites. Numerous studies have reported altered lncRNA function in cancer with a number of these lncRNAs displaying unique tissue specific expression patterns. Mutations in lncRNAs like HOTAIR, MALAT1, ANRIL, h19 and PCA3 have been reported in a number of tumor types [23, 30-34]. Interestingly, lncRNAs can display altered expression patterns in breast cancer compared to normal tissues [35-39]. In spite of the growing research findings, aimed at understanding the molecular and cellular mechanisms involved in these pathologic responses, the functional aspects of the majority of lncRNA still remains uncharacterized. In this review, we provide an update of the lncRNAs that are associated with breast development and disease, highlighting the function of known lncRNAs in these areas.

\section{Long non-coding RNA}

Using the length of non-coding RNA as a cut-off for its classification, conveniently sieves non-coding RNA into various categories such as miRNAs, siRNAs, snoRNAs, lncRNAs among other species [9, 40, 41]. LncRNAs as their name suggests, represents a class of non-protein coding transcripts which are defined as transcripts of greater than 200 nucleotides [42]. In some cases lncRNAs can also be referred to as macro lncRNA if they encompass lengths greater than $90 \mathrm{~kb}$ such as the macro lncRNAs Air and KCNQ1OT1 [43, 44]. Table 1 highlights the specific types of IncRNAs annotated thus far.

Many lncRNA have H3K27me3 methylation marks at their promoters as well as RNA PolII binding sites as an indicator of active transcription [45, 46] Many lncRNAs undergo RNA polymerase II mediated transcription followed by 5 capping, polyadenylation and even splicing $[46,47]$. However, it is important to note that not all lncRNA are polyadenylated. A fraction of lncRNAs also have a H3K4mel monomethylation mark as a sign of enhancer produced RNAs [48]. Additionally, lncRNAs can be readily identified by cross referencing high throughput RNA sequencing data with the promoter region of lncRNAs as they are enriched with histone marks such as H3K4me3, H3K9ac and H3K27ac [45, 46]. Interestingly, these histone marks are found around transcription start sites and have distribution patterns and densities correlating with protein coding and non-coding genes. Interestingly, lncRNAs share histone marks of active transcription similar to protein coding genes, however, they differ in repressive marks like DNA methylation and $\mathrm{H} 3 \mathrm{~K} 9 \mathrm{me} 3$ histone modifications [49]. The sequences of IncRNAs, their transcriptional regulation, and the additional 3D structure of these transcripts accounts for their diverse functions [50].

LncRNAs constitute the largest proportion of the non-coding transcriptome. However, recently it is has been shown that certain lncRNAs can also form complexes with ribosomes as well as giving rise to small peptides [51-56]. Thus, distinguishing some lncRNAs from other non-coding RNA. The ability of some lncRNAs to code for small peptides indicates the potential for some lncRNA to act as bifunctional transcripts giving rise to either a lncRNA or a protein template [56-58].

LncRNAs can also be classified based on their genomic organization or their relation to protein coding genes as: 1) intronic lncRNAs (produced from an intron of a gene), 2) intergenic lncRNAs (existing between two protein coding genes), 3) sense lncRNAs (overlapping one 
Table 1: Types of long non-coding RNA

\begin{tabular}{lc}
\hline Long non-coding RNA & Representative symbol \\
\hline Long intergenic non-coding RNA & LincRNA \\
Long Intronic non-coding RNA & - \\
Natural Antisense Transcript & NAT \\
Promoter associates long RNA & PALR \\
Promoter upstream Transcript & PROMPT \\
Transcribed Ultraconserved Region & T-UCR \\
Enhancer like non-coding RNA & eRNA \\
Circular RNA & circRNA \\
\hline
\end{tabular}

or more exons of a coding gene and in the same direction and strand), 4) antisense lncRNAs transcripts (arising from the opposite strands having a partial or complete sequence complementarity, 5) bidirectional lncRNAs (transcribed in opposite directions but sharing the same promoter regions with protein coding genes), and 6) enhancer lncRNAs (eRNA- produced from enhancer regions of proteins) and circular RNA [28] (Figure 1).

Another fairly recent addition to the family of lncRNAs are the circular RNAs (circRNAs). CircRNAs are abundant ncRNAs that span a range of hundreds to thousands of base pairs [59]. Additionally, they are conserved, transcribed by RNA polymerase II, occur endogenously, and were primarily thought to arise as splicing byproducts. However, high throughput sequencing and advancements in computational techniques show that these covalently closed continuous loop circular RNAs can be of many types based on their origin and sequence composition, as exonic, circular intronic or retainedintron circRNA formed either by exon back splicing or exon skipping. CircRNAs are also highly tissue and cell type specific and been observed to be developmentally regulated $[60,61]$. Though the biogenesis of circRNAs and its functional properties are still in the early stages of investigation, evidence points towards their biogenesis from circularization of single or multiple exons or a combination of an intron and exon or simply the intronic sequences alone [62-68].

The wide interactome of lncRNA elucidates to their diverse role in transcription, chromosome remodeling and intra-cellular trafficking. Furthermore, lncRNAs have been demonstrated to be involved in more functions such as transcriptional regulation, mRNA processing, mRNA maturation and epigenetic regulation through lncRNAmediated recruitment of chromatin remodelers, histone modifying complexes and DNA methyltransferases [26, 42, 69-71]. Figure 2 highlights the various functions of lncRNA in cellular signaling. Initially, lncRNAs were thought to predominantly have a nuclear function and only until recently, where reports noted their presence in the cytoplasm, has a potential role for lncRNAs in post transcriptional gene regulation, protein and transcript trafficking and shuttling been suggested [72]. Though studies pertaining to lncRNAs is still in its infancy, with only a handful of lncRNAs having been studied in detail to date, growing evidence points to their diverse role in development both in terms of tissue specificity and developmental stage $[73,74]$ (Table 2).

A number of recent reports have highlighted the differential expression patterns of lncRNAs between cancer cells versus normal cells [75-78]. Furthermore, lncRNAs can alter the activity of different hallmarks of cancer by either sustaining proliferative signaling (e.g. SRA), evading growth suppressors (e.g. ANRIL), inducing angiogenesis (e.g. MVIH), inducing invasion and metastasis (e.g. HOTAIR and MALAT1), inhibiting apoptosis (MEG3), or by enabling replicative immortality (TERC and TERRA) [23, 79-82]. For instance, the p53 pathway is regulated by the lncRNAs MEG3, MALAT1 and WRAP53 (a natural antisense transcript of p53), in a DNA damage dependent and independent manner [83-88]. Additionally, some lncRNAs are induced by p53 like lincRNAs p21, PANDA, ROR, H19 and Loc285194 all stimulating downstream p53 mediated cell cycle arrest or apoptosis [89-93]. The roles of lncRNAs towards p53 regulation showcases the complexity of the lncRNA interaction network.

Interestingly, genome wide association studies (GWAS), performed on various cancers can help us understand the genetic association of lncRNAs and cancers. It is worthy to note that single nucleotide polymorphisms (SNPs) can be involved in neoplastic progression. Importantly, a huge fraction of the SNPs lies within the non-coding intronic and intergenic regions of the genome harboring functional lncRNAs. One such interesting GWAS hotspot is the genomic locus giving rise to the lncRNA ANRIL. ANRIL is a $126 \mathrm{~kb}$ lncRNA located adjacent to INK4A/ARF locus and is linked to a number of diseases such as cancer, type-2 diabetes and coronary artery disease [94]. ANRIL interacts with the polycomb group of proteins establishing a repressed state at the INK4A/ARF locus [94-96]. Intriguingly, SNPs associated with ANRIL are phenotypically clustered, with SNPs attributed to causing vascular conditions 
appearing at the $3^{`}$ end of the ANRIL transcript while cancer susceptibility SNPs are found at the $5^{\prime}$ end of the transcript. The specific localization of SNPs along the ANRIL transcript and the altered phenotypes which are presented indicate the complexity of IncRNA function in the genome. While these SNPs may influence lncRNA stability they may also limit transcription factor binding to the INK4A/ARF locus or function in cis to regulate gene expression at other loci. It is this complexity that both continues to frustrate and intrigue. Nevertheless, a better understanding of IncRNA function will undoubtedly lead to better diagnostic and potential therapies [94].

\section{Mammary gland development and breast cancer}

During mammary gland development and pregnancy the mammary glands undergo dramatic changes in glandular morphology and cellular functions. During

A

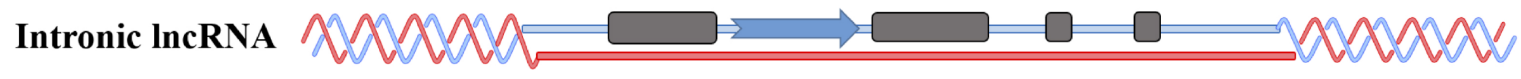

B Intergenic IncRNA

C Sense IncRNA

D Antisense IncRNA

$\mathbf{E}$ Bidirectional IncRNA 2002012

F Enhancer IncRNA

G Overlapping IncRNA

H
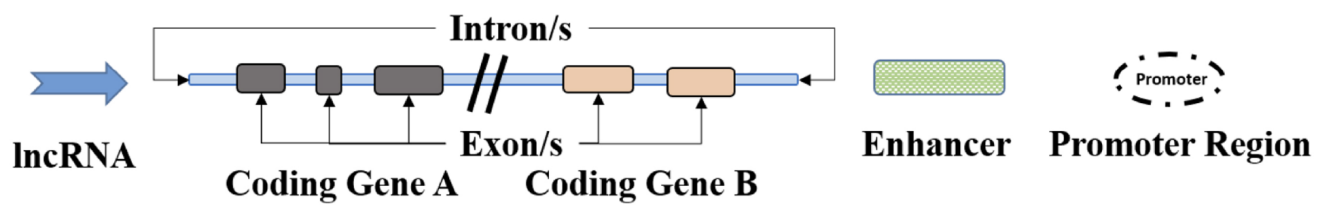

Figure 1: Genomic organization of long non-coding RNA. Intronic lncRNAs are located in an intron of a coding region (A), Intergenic lncRNAs (lincRNAs are transcripts located between two protein coding genes (B), Sense lncRNAs are transcribed from the sense strand of the protein coding genes and might overlap one or several introns and exons (C), Anti sense (AS) lncRNAs are transcribed from the antisense strand of protein coding genes and could similarly overlap with one or several introns and exons of the sense strand (D) Bidirectional lncRNAs are located within $1 \mathrm{~kb}$ of promoters in the opposite direction of protein coding transcripts (E), and Enhancer lncRNAs are located in the enhancer regions (F). Sense-overlapping lncRNAs are lncRNAs that are present within the boundaries of the protein-coding gene. Some sense lncRNAs are transcript variants of protein-coding mRNAs and may not possess a functional open reading frame for translation into proteins. Antisense overlapping lncRNAs are transcribed from the antisense strand and overlap in part with well defined spliced sense or intronless sense RNAs and undergoes fewer splicing event and has lower abundance than sense transcripts (G). Circular RNAs are generated usually by backsplicing wherein a downstream splice donor is fused with an upstream splice acceptor. Such circRNAs can consist of one or more exons and can even contain unspliced intronic sequences $(\mathbf{H})$. 
embryogenesis, these transformations are directed by signals from the surrounding mesenchyme, but during puberty and into adulthood, circulating hormones released from the pituitary and ovary provide additional instructive input [5]. The human breast consists of a mélange of parenchymal and stromal elements. While the former gives rise to the branching ducts, which eventually leads to the development of secretory acini, the later consists mainly of adipose tissues involved in providing a suitable environment for parenchymal development [5, 97-99]. In puberty, hormonal stimulation initiates further differentiation of acini branching morphogenesis, which is halted in early childhood to develop into a mature mammary gland $[100,101]$. Intriguingly, the mammary gland undergoes immense rounds of development and differentiation, which are linked to the distinct stages of sexual development from puberty to adulthood and reproduction. A mixture of different cell types, comprising epithelial cells, adipocytes, vascular endothelial cells and stromal cells converge to form the secretory organ, the mammary gland. During mammary gland development these different cell types engage in an extensive crosstalk mediated by hormones, growth factors, and cytokines to ensure correct organization of the breast (Figure 3). Adipocytes are a major constituent of the stromal fat pad in mature non-lactating mammary glands. Furthermore,

\section{A Transcriptional Activation}

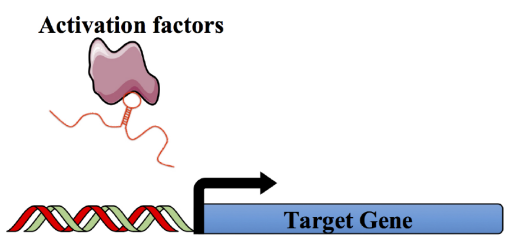

D
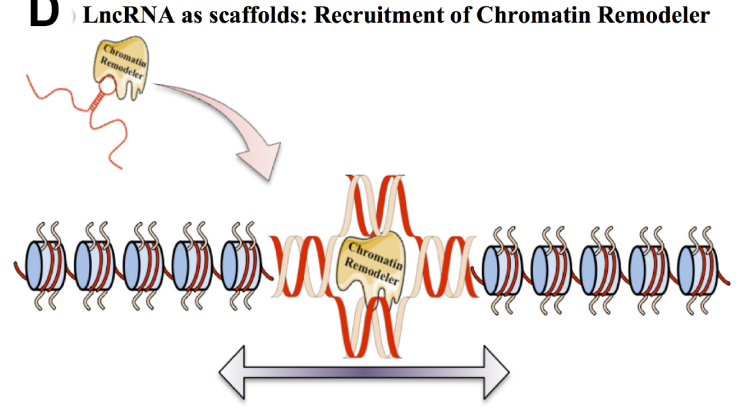

F Splicing Control

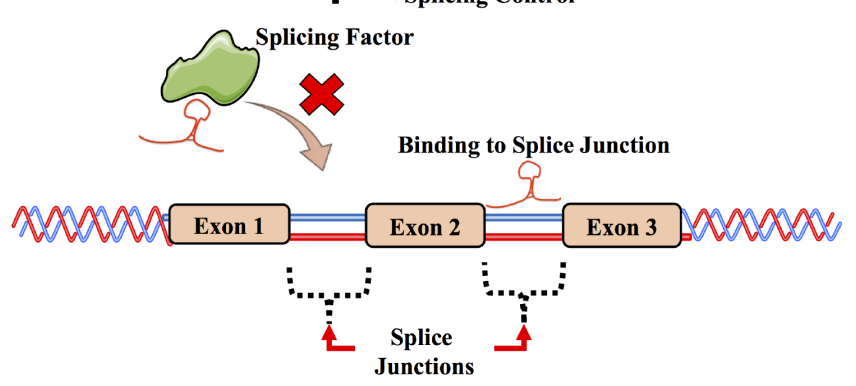

B Transcriptional Repression

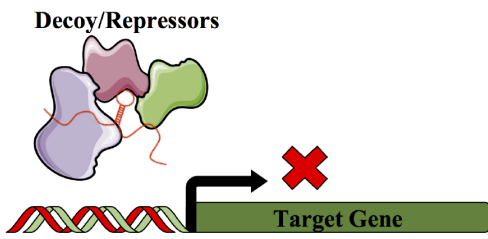

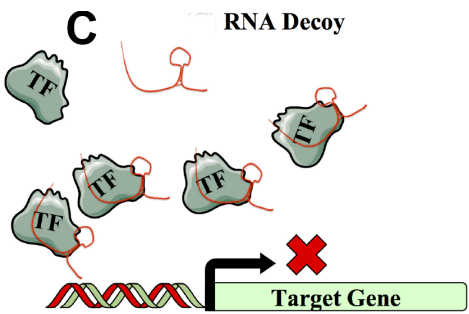

E Epigenetic Modifications

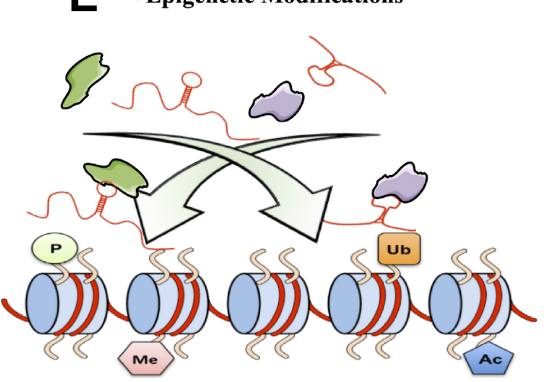

G Sequestration of miRNA

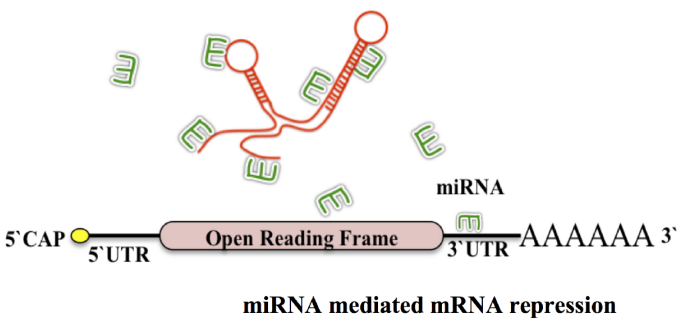

Figure 2: Functions of long non-coding RNA. Long non-coding RNA, have diverse mechanisms of functions mainly owing to their sequence, 3D structures and diverse interacting partners. Some of the functions are as follows. LncRNAs interact with transcriptional activators and are involved in target gene activation (A). Likewise lncRNAs have also been shown to be involved in transcriptional repression by preventing transcriptional activators from accessing the promoter (ex. XIST or SRG1) (B). Additionally, lncRNAs behave as decoys sequestering transcription factors or other activation complexes interfering and directly affecting or regulating the signaling pathways by diluting them from their target regions (ex. GAS5 or H19) (C). Additionally they can also recruit transcriptional repressors and ultimately lead to transcriptional repression of target genes. IncRNAs also serve as scaffolds, providing a platform for recruiting chromatin remodelers and other ribonucleoproteins (RNPs) directing changes in the chromatin structure (ex. HOTAIR or Six3OS). (D). LncRNAs are also involved in bringing about epigenetic changes in the chromatin. The epigenetic changes (activation or repression marks) brought, depends on the epigenetic marks such as phosphorylation, acetylation, ubiquitination or methylation (ex. XIST and HOTAIR) (E). LncRNAs are involved in regulating RNA splicing by interacting with the splicing factors or by binding the splicing junctions of premRNA (ex. asFGFR2) (F). LncRNAs also serve as molecular sponges by harboring binding sites for miRNAs and titrating or diluting them away from their miRNA targets (ex. linc-ROR and H19) (G). 
Table 2: Long non-coding RNAs in breast cancer and their genomic organization

\begin{tabular}{ll}
\hline IncRNA in breast cancer & Genomic organization \\
\hline ARA, BC200, CCAT2, SPRY4-IT1 & Intronic lncRNA \\
H19, MALAT1, MEG3, LincROR, HOTAIR, XIST, UCA1, LINC00324, LSINCT5 & Intergenic lncRNA \\
XIST & Sense lncRNA \\
HOTAIR, ANRIL, ZFAS1 & Antisense lncRNA \\
H19, SOX2OT & Overlapping lncRNA \\
CUPID1 and CUPID2 & Bidirectional lncRNA \\
P53-eRNA & Enhancer lncRNA \\
Circ-ABCB10 & Circular lncRNA \\
\hline
\end{tabular}

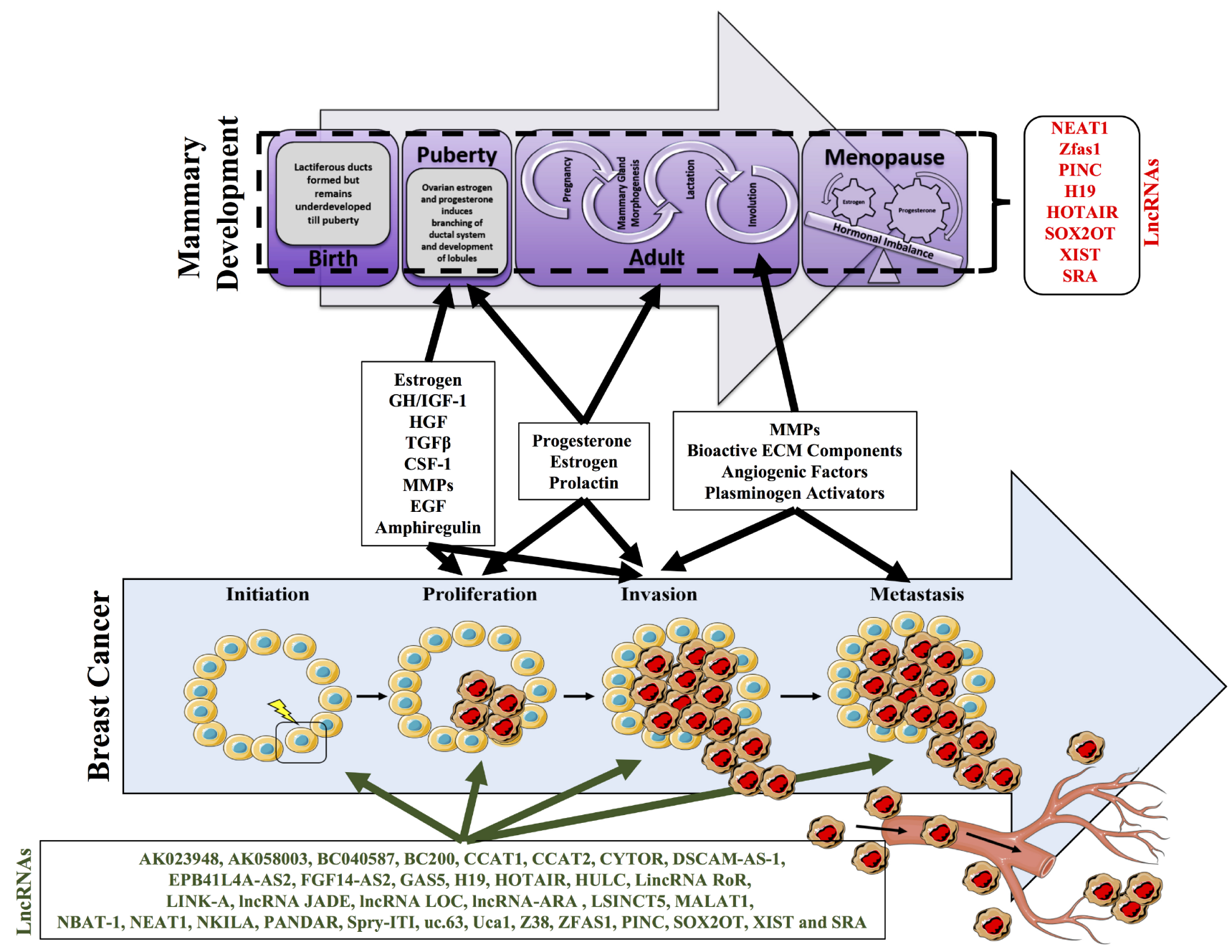

Figure 3: Mammary development with respect to the developmental stages. Postnatal mammary gland development is composed of several stages and undergoes tremendous remodeling and morphogenesis. Highlighted are the key changes that occur at birth, puberty, adult and menopause. At birth lactiferous ducts are formed but remain underdeveloped until puberty. At puberty ovarian estrogen and progesterone induces the branching of ductal systems and development of lobules. The adult stage marks an important stage of development wherein the onset of pregnancy triggers mammary gland morphogenesis. Additionally, milk ducts are formed that emanate into the nipple. Subsequently post pregnancy, involution occurs wherein all the lactiferous ducts are disintegrated. The onset of menopause can impact on the tightly regulated hormonal levels and can tip off an imbalance in the hormonal levels. A number of lncRNAs have suggested to be involved in these processes including, NEAT1, ZFAS1, PINC, H19, XIST, SRA, HOTAIR, AND SOX2OT). Importantly alterations in the factors required for mammary gland development and involution, may further modify the ability of cells to undergo neoplastic transformation required for breast cancer progression and metastasis. 
adipocytes present in the mammary gland also express aromatase enzymes that help in the conversion of the androgens to estrogen exhibiting a paracrine effect on estrogen receptor-a positive epithelial cells. Additionally, adipocytes regulate angiogenesis in the mammary gland by the secretion of VEGF- vascular endothelial growth factors. Apart from adipocytes found in the mammary gland another principal component of the mammary gland is fibroblasts. Fibroblasts secrete growth factors, which in turn regulate the epithelial cell survival, proliferation and differentiation during morphogenesis. Fibroblasts can maintain the extra cellular matrix (ECM) through collagens, proteoglycans and fibronectins whilst simultaneously leading to the degradation and remodeling of the ECM by expressing enzymes such as matrix metalloproteinases.

This highlights the remarkable plasticity of cells within the mammary gland. However, this is never truer than during pregnancy where the breast undergoes a cyclic transformation wherein the non-functioning gland matures into an organ producing milk. It returns back to a normal resting non-functional mammary gland once the production of milk is ceased (Figure 3). This is also referred to as the pregnancy lactation cycle (PLC) and has been shown to alter the molecular histology of the breast with tremendous cellular remodeling, morphological changes including cell death during involution.

It has been observed in mouse models that involution post lactation is a complex process involving more than 50 differentially expressed genes regulating a myriad of distinct molecular pathways and developmental processes [102]. During postlactational involution, the dissolving of tissue architecture along with the additional activation of factors within the tumour microenvironment could lead to the development of premalignant cells in mammary gland [103]. When the extracellular matrix isolated from mammary glands was compared between nulliparous or the postlactational mice, tumorigenic ECM fragments that promote outgrowth of breast cancer cells in culture were found in the mammary glands undergoing remodeling [104-107]. This additionally promoted breast cancer metastasis in animal models [104-107]. While these model systems have demonstrated an increased likelihood for tumor developmental, data supporting this is very sparse $[106,107]$. It is more than likely that any significant delay in the postlactational involution may increase cancer formation risk potentially through the deregulation of microenvironmental influences within the mammary gland [103, 108]. Intriguingly, cancer linked to lobular involution may be an age related protective process with early pregnancies demonstrating a statistically significant lower incidence of breast cancer versus pregnancies in older women $[109,110]$. Nevertheless, nulliparous women have a $20 \%-40 \%$ higher risk of postmenopausal breast cancer than parous women who first gave birth before age 25 [111]. A potential simple explanation for the reduced risk for breast cancer is the removal of the epithelial cells during the involution process thus eliminating any progenitor cancer stem cells required for the formation of the tumors $[110,112]$.

Hormones are critical factors in mammary development. A spike in the levels of progesterone and estrogen during pregnancy is observed with the concentrations of both hormones decreasing rapidly postpartum $[113,114]$. This splurge in hormone levels during pregnancy may increase the risk of breast cancer in the short term, in particular for certain hormone sensitive cancer subtypes. However, the mechanisms governing the protective long-term anti-cancer effect is likely to be more complex with both age of first pregnancy and efficient involution of the terminal duct lobular units being just two of the factors involved in neoplastic growth. In addition, elevated levels of testosterone and estrogens have been documented in postmenopausal women and shown to positively correlate with increased breast cancer risk. Increased levels of androgens during pregnancy has also been associated with shorter breast feeding durations [115]. Interestingly, high levels of circulating androgens can be used as a biomarker for increased cancer risk in premenopausal women [116-118]. Additionally, elevated levels of prolactin, a hormone involved in normal breast development and lactation, is associated with a slight increase in breast cancer risk in both pre and postmenopausal women and is important in the etiology of breast cancer [119, 120]. Listed above are just some of the factors regulating mammary gland development and likewise breast cancer tumorigenesis. Furthermore, it is important to note that breast development is regulated by a transcriptional cascade that enables the concerted action of a number of cellular developmental processes with intrinsic or acquired alterations to any of the genetic components involved in these processes potentially driving breast cancer progression.

Breast cancer, as previously mentioned is a very heterogeneous disease and a number of key factors and biological features are considered for prognostic, diagnostic and predictive purposes. Many of such practices include histological grade, hormone receptor status, and lymph node status. With respect to gene expression, breast cancer is classified into 5 subtypes namely luminal A, luminal B, basal-like (also known as triple negative breast cancer), ERBB2+, and normal breast-like subtype [121]. The majority of these revolve around estrogen receptor (ER) and or progesterone (PR) receptors status, with the ER and PR positive tumors usually falling under the luminal subtypes further bifurcating into the two major classes luminal A and luminal B based on their Ki67 expression levels [122]. Like ER and PR, the ERBB2+ subtype or HER2+ subtype as it is commonly known is characterized by overexpression of the HER 2 receptor. Tumors lacking all three receptors (ER-, PR-, HER2-) are classified into a triple negative subtype. Interestingly, the 
normal like subtype is characterized by its gene expression pattern, which is similar to that of normal breast but could have neighboring cancer cells infiltrating into its cellular matrix [123, 124]. A thorough and detailed diagnosis of these subtypes helps in associating the patient to the treatment regimen they should receive. Interestingly, patients falling under the same combination of features mentioned above can still follow different clinical paths restricting breast cancer therapy and emphasizing the need of personalized treatment.

\section{Non-coding RNA in mammary development}

Mammary development remains an important field of research owing to the different stages of differentiation and remodeling. It is therefore important to dissect the pathways that control mammary development and differentiation at the cellular level. Irrespective of the immense research carried out towards understanding mammary development recapitulating the architecture and physiological intricacies during pregnancy still remain vague. More than 100 genes, including hormone directed regulation of specific proteins and other signaling pathway related genes are said to be involved in controlling mammary physiology from remodeling to involution. Interestingly, research carried out on the mouse mammary gland has elucidated the precise roles of some of transcription factors involved in or promoting the differentiation of luminal progenitors into ductal or alveolar cells [125]. Oncogenic initiating events targeting particular progenitor cells during mammary gland development through the action of such transcriptional regulatory networks could give rise to different outcomes with respect to the cancer subtypes [126, 127].

As mentioned, many coding genes have been well documented with regard to their roles in regulating embryonic, post-natal and post pubertal mammary gland development [126, 128-130]. The role of miRNAs in mammary gland development has been extensively studied, with a comprehensive miRNA profiling of the postnatal mammary gland having been carried out in mouse covering all the major stages of development including juvenile, puberty, mature virgin, gestation, lactation and involution stages [131]. This study highlights the importance of ncRNA in mammary development. A recent study also showcased a panoramic view of the lncRNAs in the bovine mammary gland and suggested their association with biological functions and also their involvement and susceptibility to clinical mastitis and eventually their milk quality and milk production. Such extensive annotation of the mammary gland and associated lincRNAs helps understand the bovine mammary gland biology [132]. However, the role of lncRNAs in the development of the mammary gland remain largely unexplored. Unlike proteins and miRNAs, lncRNAs are much less annotated and characterized. Interestingly, a few
lncRNAs have been documented in literature as having a potential role in mammary gland development and are listed below (Figure 3).

Nuclear Paraspeckle Assembly Transcript 1 (Neat1) is an important architectural component of the paraspeckle nuclear bodies. Neat-1 paraspeckes have previously been identified as key regulators of gene expression effecting transcription factors and hyperediting mRNAs, however, it still remains unknown as to whether they have a biological relevance or under what physiological conditions these parascpeckles are formed in vivo. Standeart and colleagues showed that these parascpeckles are assembled in the luminal epithelial cells during mammary gland development [133]. Interestingly, the ablation of Neat1 results in an abnormal mammary gland morphogenesis and additional defects in lactation as well. The authors observed that this lactation defect is caused by the decreased ability of Neat1 mutant cells to sustain high rates of proliferation during lobular-alveolar development. This pioneering study shows the striking role of a lncRNA in mammary gland development and lactation in mice and paved way for further investigation.

H19 is highly expressed in alveolar cells during pregnancy and involution. H19 is an imprinted gene and has been demonstrated to be developmentally regulated with transcript levels increasing during both puberty and pregnancy [134]. Additionally H19 is also expressed in the uterus and is particularly high during the estrus and metestrus phases [134]. This same group demonstrated regulation of $\mathrm{H} 19$ by estradiol and corticosterone, both in vitro and in vivo, and in MCF-7 cell lines. Increased H19 levels were also detected in ovariectomize and adrenalectomised mice [134].

SRA (Steroid receptor RNA activator) is activated by steroid hormones and has been suggested to play a role in post pubertal mammary gland development [135]. The generation of a transgenic SRA mouse model where expression of the SRA gene was under the mouse mammary tumor virus long terminal repeat (MMTV) promoter demonstrated SRA expression in the nuclei of luminal epithelial cells of the mammary gland $[135,136]$. The authors observed that although early ductal outgrowth was comparable between wildtype and SRA-transgenic strains in the adult virgin mice enhanced SRA expression led to an abnormal branching morphology in the transgenic duct. Furthermore, during pregnancy, progression of lobulo-alveolar structures was potentiated compared to control mice. However, while a strong correlation does exist between different physiological roles of steroid receptors, in particular the progesterone receptor, and the RNA transcript SRA in the regulation of development, the role of SRA in mammary gland development remains inconclusive as their RNA levels are barely detectable in virgin mouse mammary glands [135].

Zfas1 has recently been described as a novel regulator of mouse mammary development. Zfas 1 is a 
transcript that is differentially expressed antisense to the 5 end of the protein coding gene ZNFX1. Zfas1 is localized within the ducts and alveoli of the mammary gland and hosts three snoRNAs (SNORDs): Snord12, Snord12b, and Snord12c [137]. Furthermore, Zfas 1 transcripts are highly stable with their knockdown leading to increased cellular proliferation and differentiation without affecting overall SNORD levels. The human ortholog ZFAS1 has similar features to Zfas1, wherein both are highly expressed in the mammary gland and downregulated in tumors highlighting the potential tumor suppressor gene properties along with their regulatory role in alveolar development and epithelial cell differentiation $[137,138]$. Interestingly it has recently been shown ZFAS1 is associated with ribosomes and could play a role in regulating their assembly or biosynthetic activity. Expression levels of ZFAS1 and ribosomal protein coding mRNAs involved in ribosome assembly, production and maturity have a tight correlation, with the knockout of ZFAS1 reducing RPS6 phosphorylation significantly [139].

Pregnancy induced Non-coding RNA (PINC) is a developmentally regulated non-coding RNA that is expressed in the parous mammary gland at the regressed terminal ductal lobular unit like structures [140]. Thus, PINC and ZFAS1, are both expressed during post pubertal mammary gland development, particularly in the alveolar cells during pregnancy. Interestingly, both these lncRNAs have decreased expression during lactation and an increased expression during early involution. Signifying that PINC expression is likely to be temporally and spatially regulated in response to developmental stimuli. One proposed mechanism of the role of PINC in mammary gland development is through the regulation of chromatin modifying complexes. PINC interacts with the retinoblastoma associated protein 46 ( $\mathrm{RbAp} 46)$, a component of the polycomb repressive complex 2 (PRC2), repressing gene expression. Although both PINC and $\mathrm{RbAp} 46$ are both upregulated in alveolar cells of the mammary gland during pregnancy it is now known that PINC likely functions to inhibit terminal differentiation of alveolar cells during pregnancy to prevent abundant milk production and secretion until parturition [141].

Hox Transcript antisense intergenic RNA (HOTAIR) is localized within the HoxC gene cluster. During mammalian embryonic development Hox genes, which are highly gene dense regions, are tightly regulated by the IncRNA HOTAIR. HOTAIR has been documented to downregulate HoxD gene expression which has previously been shown to be required for mediating the differentiation of the mammary epithelium ductal system in response to pregnancy [142]. Interestingly, HOTAIR functions in trans by increasing $\mathrm{PRC} 2$ recruitment to the genomic regions of target genes, repressing gene transcription [143]. A complete overview of HOTAIR and its role in chromatin dynamics has been extensively reviewed by
Bhan and colleagues [144]. It is important to note here that the knockout of HOTAIR does not have an evident phenotype in the mouse mammary gland even though the PRC2 complex has been predicted to maintain a population of alveolar differentiated cells in the involuted gland. Furthermore, the actions and effects of Hotair, though widely studied, remain controversial. Targeted deletion of a 4 kilobase region within the HoxC cluster results in a severe skeletal phenotype. In contrast mice harbouring a complete deletion of the HoxC locus display no abnormal skeletal abnormalities or any changes in HoxD expression $[145,146]$. Indicating that the complexity of this locus and the specific function of HOTAIR in this regard remains undetermined. HOTAIR has been observed to be involved in the regulation of cancer cell proliferation and cancer invasion in breast cancer which could arise from the positive correlation between HOTAIR and Hoxc11 genes [146]. Interestingly, HOTAIR is also regulated by estrogen and acts through estrogen receptors in ER+ breast cancer patients eluding to a feedback loop between the lncRNA and hormonal levels in normal individuals [147].

SOX2OT harbors the Yamanaka transcription factor SOX2 and is essential for maintaining pluripotency in a variety of stem cells. It is highly functional during embryonic development and is involved in stem cell maintenance. SOX2 and SOX2OT are differentially expressed in estrogen receptor positive and negative breast cancer tissues. SOX2 has also been shown to be critical determinant in mammary development [148]. Interestingly, the ectopic expression of the overlapping transcript leads to a massive increase in SOX2 expression levels, suggesting it plays a key role in the maintenance of SOX2 expression in breast carcinoma [149]. However, like HOTAIR as of yet there is no direct link of SOX2OT involvement in mammary gland development, but due to their critical roles in embryonic development and links to breast cancer they have included here.

In addition to these 6 candidate genes, a study performed on core needle biopsies from 42 nulliparous and 71 parous postmenopausal women analyzed differentiation associated gene expression within these two groups [150]. Interestingly the nuclei of epithelial cells were large and euchromatic in nulliparous breast cells and small and hyperchromatic in parous postmenopausal breast cells. Transcriptomic analysis recorded around 267 upregulated probe sets comprising genes involved in chromatin condensation, transcription regulation, splicing machinery and expectantly a number of non-coding RNA elements such as XIST, NEAT1, MALAT-1, CXorf50B, NCRNA00173 and NCRNA00201 [150]. These lncRNA molecules are all known to recruit the polycomb group of proteins that lead to the condensation of chromatin. MALAT-1 is upregulated by oxytocin during lactation, and both oxytocin specific receptor OTR and MALAT-1 are both upregulated in the breast of postmenopausal 


\begin{tabular}{|c|c|c|c|}
\hline $\begin{array}{l}\text { Non-Coding } \\
\text { RNA }\end{array}$ & Category & Function & Reference \\
\hline XIST & $\operatorname{lncRNA}$ & $\begin{array}{l}\text { Differentially expressed in transcriptomic analysis } \\
\text { between nulliparous and parous post-menopausal } \\
\text { women. } \\
\text { Important in embryonic development } \\
\text { Recruitment of polycomb group of proteins. }\end{array}$ & {$[150]$} \\
\hline NEAT1 & lncRNA & $\begin{array}{l}\text { Differentially expressed in transcriptomic analysis } \\
\text { between nulliparous and parous post-menopausal } \\
\text { women. } \\
\text { Recruitment of polycomb group of proteins. }\end{array}$ & {$[150]$} \\
\hline MALAT1 & $\operatorname{lncRNA}$ & $\begin{array}{l}\text { Differentially expressed in transcriptomic analysis } \\
\text { between nulliparous and parous post-menopausal } \\
\text { women. } \\
\text { Recruitment of polycomb group of proteins. }\end{array}$ & {$[150]$} \\
\hline H19 & $\operatorname{lncRNA}$ & $\begin{array}{l}\text { Regulated by estradiol and corticosterone. } \\
\text { Highly expressed in alveolar cells during pregnancy } \\
\text { and involution. } \\
\text { Function in mammary gland development still } \\
\text { unclear. }\end{array}$ & {$[134]$} \\
\hline SRA & $\operatorname{lncRNA}$ & $\begin{array}{l}\text { Activated by steroid hormones. } \\
\text { SRA overexpression leads to cellular proliferation } \\
\text { and differentiation accompanied by apoptosis but } \\
\text { doesn’t progress to malignancy. } \\
\text { Function in mammary gland development still } \\
\text { unclear. }\end{array}$ & {$[135]$} \\
\hline ZFAS1 & $\operatorname{lncRNA}$ & $\begin{array}{l}\text { Suppresses mammary epithelial cell proliferation } \\
\text { and differentiation. } \\
\text { Expressed in post pubertal mammary gland } \\
\text { development particularly in alveolar cells during } \\
\text { pregnancy. }\end{array}$ & {$[137,248]$} \\
\hline PINC & $\operatorname{lncRNA}$ & $\begin{array}{l}\text { Expressed in parous mammary gland at the } \\
\text { regressed terminal duct lobular unit like structures. } \\
\text { Expressed in post pubertal mammary gland } \\
\text { development particularly in alveolar cells during } \\
\text { pregnancy. }\end{array}$ & {$[140]$} \\
\hline NCRNA00201 & lncRNA & $\begin{array}{l}\text { Differentially expressed in transcriptomic analysis } \\
\text { between nulliparous and parous post-menopausal } \\
\text { women. } \\
\text { Function in mammary gland development still } \\
\text { unclear. }\end{array}$ & {$[150]$} \\
\hline NCRNA00173 & $\operatorname{lncRNA}$ & $\begin{array}{l}\text { Differentially expressed in transcriptomic analysis } \\
\text { between nulliparous and parous post-menopausal } \\
\text { women. } \\
\text { Function in mammary gland development still } \\
\text { unclear. }\end{array}$ & {$[150]$} \\
\hline HOTAIR & $\operatorname{lncRNA}$ & $\begin{array}{l}\text { Is dispensable in mouse mammary development. } \\
\text { Is induced by estrogen through GPER receptors. } \\
\text { Function in mammary gland development still } \\
\text { unclear. }\end{array}$ & {$[146,147]$} \\
\hline SOX2OT & lncRNA & $\begin{array}{l}\text { Increases SOX } 2 \text { expression and may play a role in } \\
\text { maintaining pluripotency in mammary stem cells. } \\
\text { Function in mammary gland development still unclear }\end{array}$ & [149] \\
\hline
\end{tabular}


Differentially expressed in transcriptomic analysis

between nulliparous and parous post-menopausal

CXorf50B IncRNA

women.

Function in mammary gland development still

unclear.

women, including in conditions where the circulating oxytocin is absent [150]. Similarly, XIST is upregulated in $\mathrm{X}$ chromosome inactivation upon differentiation. XIST repression occurs during early embryogenesis in undifferentiated ES cells by the binding of NANOG, OCT4 and SOX2 to the XIST gene, a similar phenomenon is exhibited in malignancies [151, 152]. Up-regulation of DDX, SOX1, SOX6 and SOX17 in postmenopausal nulliparous breast may also play a role in the regulation of XIST transcription similar to the pluripotency factors [150]. Table 3 summarizes the role of lncRNAs involved in mammary gland development. However, it is important to mention here that the majority of data summarized above extrapolates the potential of IncRNAs in mammary development based on correlative expression data with only a few lncRNAs having been directly implicated in mammary gland development.

\section{LncRNAs in breast cancer}

Although the roles of lncRNA are too numerous to discuss individually Supplementary Table 1 covers some of the lncRNAs that have been implicated in breast cancer. Nevertheless, we will discuss in detail the roles of the some of the lncRNAs involved in breast cancer below. It is important to indicate that a number of inconsistencies between various studies were noted potentially arising from the bioinformatics pipelines used in the individual studies, the different use of cell lines, or the different use of sequencing technologies. These inconsistencies are likely to be also dependent upon the intrinsic genetic heterogeneity of individual tumors.

$\mathrm{X}$ inactive Specific Transcript (XIST) is one of the most well studied long non-coding RNAs. Initially discovered in the early 90's it has been implicated in breast cancer progression. This lncRNA arises from the $\mathrm{X}$ inactivation center (XIC) nested within the $\mathrm{X}$ chromosome and which plays an important role in $\mathrm{X}$ chromosome inactivation [153]. Interestingly, many have reported the XIST expression correlates with the absence of a detectable Barr body in somatic cells, a strong cytological marker of the inactive $\mathrm{X}$ chromosome (Xi) $[154,155]$. Furthermore, in human cancers a deregulation of XIST expression along with the loss of the normal X chromosome has been observed [156, 157]. XIST has also been shown to interact with BRCA1, a gene frequently mutated in triple negative breast cancers (TNBC) further implicating its role in breast cancer [158-162]. However, another group was able to show that in spite of increased copy numbers of the $\mathrm{X}$ chromosome, none of them are inactivated, irrespective of the BRCA1 status [163]. While the loss the $\mathrm{Xi}$ and the replication of active $\mathrm{X}$ chromosome $(\mathrm{Xa})$ was observed in sporadic cancers and basal like breast cancers they were rarely seen in nonbasal like breast cancers [164]. The role of BRCA1 and the localization of XIST on the Xi was widely debated and this heterogeneity of $\mathrm{X}$ chromosome inactivation (XCI) status was later attributed to the increased order of $\mathrm{X}$ chromosome instability, in addition to the loss of $\mathrm{Xi}$ [159, 165-167]. As mentioned XIST is crucial for XCI an effect accomplished through the recruitment of the PRC2 complex and induction of histone condensation and transcriptional inhibition [168-172]. X chromosome inactivation over the past decades has propelled our understanding of how XIST is transcribed, localized, silenced and eventually maintained [168, 169].

A number of factors are required for these steps to be establish on the inactive $\mathrm{X}$ chromosome. Recent work has established that HNRNPU, also known as SAF-A, anchors the lncRNA to the X chromosome while, SHARP recruits HDAC3 permitting PRC2 components to introduce repressive histone marks [173-177]. The recent high throughput studies of XIST interactors and regulators of XCI use varying techniques have further identified many more potential XIST interactors [173, 174, 178-181]. Intriguingly, there are discrepancies in the number of proteins pulled down, owing mainly to the strategies used, the crosslinking techniques and the cell lines used. BRCA1, being a tumour suppressor was observed in many cases to be mutated in patients with breast and ovarian cancer and was proposed to support the concentration of XIST on the inactive X chromosome [160]. However, this remains widely disputed with studies that followed showing that BRCA1 mutated primary breast tumours could still have one or more XIST RNA coated chromosomes [159, 166]. While these studies do not completely eliminate the role of BRCA1 in X inactivation, it still may be that BRCA1 could impact transcriptional regulation on a genome wide level by acting as a transcriptional regulator [182]. Additionally, while BRCA1 does not possess a consensus DNA binding sequence, it does contain many transcription factor binding sites suggesting the presence of BRCA1 at specific promoters as part of an inactive. BRCA1 would then revert to an active complex through the activation of certain stimuli like those stemming from DNA damage responses 
[182]. Another important chromatin modulator Aurora B Kinase has also been linked to cancer susceptibility owing to its role in chromosome segregation and cell division [183]. Aurora Kinase B regulates XIST RNA binding to the heterochromatin through phosphorylation of $\mathrm{H3}$, regulating its association with the inactive $\mathrm{X}$ chromosome by means of anchor points within XIST [184]. A fairly recent study by Heard and colleagues showed that breast cancer cell lines and breast tumours exhibited abnormal 3D nuclear organizations and perturbations on a global scale. This was marked by an increase in euchromatic marks and an abnormal distribution of H3K27me3 repression marks along with increased DNA methylation at the promoters. Reactivation of many genes leading to epigenetic instability was observed in primary breast tumours and the disappearance of the epigenetic marks that build up on the inactive $\mathrm{X}$ chromosome leading to the disappearance of the Barr body in breast cancer cells [185]. The aggressiveness of the cancer though marked by the disappearance of the Barr body could correspond to the reactivation of the lncRNA or simply to its genetic loss. The status of XIST and the exact consequences therein on the Xi still remains unclear and is poorly understood with respect to cancer and requires further investigation.

HOTAIR is one of the first lincRNAs to be reported and associated with the development of cancer and also the first lincRNA to regulate genes at a distance [186]. As indicated above, HOTAIR though transcribed from the HOXC locus has a more distal mode of action functioning in trans on the HOXD locus accounting for a widespread decrease in expression levels of multiple HOXD target genes [143, 186, 187]. HOTAIR interacts with two key regulators of chromatin dynamics PRC2 and histone demethylase LSD1. Interestingly, HOTAIR functions through a bifunctional mechanism to regulate both proteins. HOTAIR interacts with PRC2 through its 5 ' end enhancing repression of PRC2 target loci. In contrast HOTAIR interacts with LSD1 through its 3' end similarly regulating gene silencing. While PRC2 brings about methylation of the H3K27, LSD1 carries the demethylation of the H3K4 histone marks. Importantly, methylation signatures acquired from tumours exhibiting altered HOTAIR expression have been predicted to function as a biomarker for poor prognosis in various cancers and therapy resistance [188]. HOTAIR has been shown to promote cancer cell proliferation, invasion and metastasis and it is therefore no surprise that HOTAIR has been shown to be overexpressed in several types of cancers [189-192]. Interestingly, HOTAIR is highly expressed in breast cancer compared to normal breast epithelium with recent evidence indicating the increased detection of HOTAIR in peripheral blood mononuclear cells and breast cancer tissues from ER+ and TNBC patients [147]. HOTAIR is also an independent biomarker for predicting the risk of metastasis and mortality in breast cancer with high expression levels of HOTAIR correlating with decreased prognosis. Intriguingly, HOTAIR serves as an independent predictor of metastasis in patients with ER+ breast cancer but not in patients with ER- breast cancer [193]. Experimentally, in vivo and in vitro overexpression of HOTAIR increases the invasive nature of breast cancer cells. This overexpression of HOTAIR was positively correlated with DNA methylation in primary breast cancer [194]. The process of metastasis involves the coordination of multiple factors including the establishment of epithelial to mesenchymal transition (EMT). In addition, the maintenance of a cancer stem cell population has also been shown to play an important role in cancer metastasis [195, 196]. Interestingly, when HOTAIR is overexpressed, EMT is induced, and the self-renewal capacity of cancer stem cells is maintained [197]. In contrast, upon depletion of HOTAIR both the ability of cells to undergo EMT and overall cancer stem cell populations were diminished. This was further demonstrated in gastric cancer where suppression of HOTAIR reversed the EMT process [198]. The authors go on the show that HOTAIR targets the intercellular adhesion molecule ICAM-1 and members of the matrix metalloproteinase family (MMP1, MMP3 and MMP9) in gastric cancer. MMPs trigger metastasis by remodeling the extra cellular matrix and destroying the basement membrane and when HOTAIR is suppressed MMP1 and MMP3 are also suppressed. HOTAIR also increases the expression of SNAIL, a potent EMT inducer [199]. Furthermore, HOTAIR is involved in the regulation of epithelial cell to cell interactions by increasing the degradation of ATAXIN-1 through ubiquitin mediated degradation, limiting ATAXIN-1 mediated transcription of E-CADHERIN [200-203]. Another way in which HOTAIR can promote metastasis is through its binding to miR 331-3p, resulting the increased expression of HER2. MDA-MB-231 has low levels of HOTAIR expression however, when MDA-MB-231 cells overexpressing HOTAIR were injected in mice tails, an 8-10 fold increase of nodules in the lung was observed suggesting HOTAIR as a positive regulator of metastasis [30,143]. Similarly, another non-metastatic cell line with low HOTAIR levels SK-BR-3 showed similar effects of metastasis to the lungs but disappeared after a week probably because of its lack of genetic elements allowing tumor persistence in the lungs [143]. Though these initial experiments are indicative of the pro-metastatic properties of HOTAIR the molecular mechanism of how HOTAIR might be involved in EMT and cancer stem cell self renewal might be more complex than thought and further research is undoubtedly required. External factors and exposure to chemical agents can also trigger the differential regulation of IncRNAs. HOTAIR is transcriptionally upregulated by estradiol and is dysregulated by bisphenol-A (BPA) and diethylstilbestrol (DES) [204]. Within the HOTAIR promoter estrogen response elements (ERE) are triggered by BPA and DES through a series of estrogen receptor regulators such as MLL histone methylases (MLL1 and 
MLL3) which modify the chromatin structure leading to gene activation [204]. This study suggests that the epigenetic status can be altered by exposure to chemical agents leading to a cascade of events such as endocrine disruption. Figure 4 outlines the proposed mechanism for HOTAIR mediated gene silencing in breast cancer.

Along with its role in mammary gland development NEAT1 has also been observed to behave as an oncogene, by promoting proliferation and metastasis in breast cancer patients [205]. LncRNA NEAT1 is highly expressed in breast cancer tissues and expression correlates with tumour size and metastatic potential [205]. RNA immunoprecipitation coupled with high throughput sequencing showed that NEAT1 was associated with FOXN3 and SIN3A repressor complex in ER+ cells. This NEAT1FOXN3-SIN3A nucleoprotein complex was demonstrated to enhance EMT, invasion and metastasis potentially through the downregulation of the EMT inhibitor GATA3, a direct target of this repressor complex. Interestingly, elevated levels of FOXN3 and NEAT1 correlated with higher histological grade and poorer overall survival in breast cancer [206].

SRA modulates the function of steroid receptors such as estrogen and progesterone along with other transcription factors both at the RNA level and the protein level. This transcript is also highly expressed in numerous cancers including breast cancer suggesting its potential role as a steroid dependent modulator of tumorigenesis. In the aforementioned SRA mouse model, overexpression of SRA lead to an induction of epithelial hyperplasia accompanied by an increase in apoptosis. However, SRA expression itself, is insufficient to promote malignancy [135]. Furthermore, proliferation, inflammation and apoptosis are all induced when SRA is overexpressed in estrogen, progesterone or testosterone sensitive tissues in both male and female mice elucidating to its role in tissue homeostasis in hormone sensitive cells. Early on SRA was thought only to act as non-coding RNA; however, several isoforms of SRA are capable of encoding the endogenous protein (SRAP). The expression of either these two transcripts is controlled by alternative splicing of intron-1, whose retention alters the SRAP reading frame. Nevertheless, it has been observed that both SRAP and the non-coding SRA can co-exist in breast cancer cell lines. Using antisense oligonucleotides to specifically upregulate SRA RNA intron 1 level resulted in marked changes in plasminogen urokinase activator, ER $\beta$, and NME1 expression altering the tumorigenic potential of

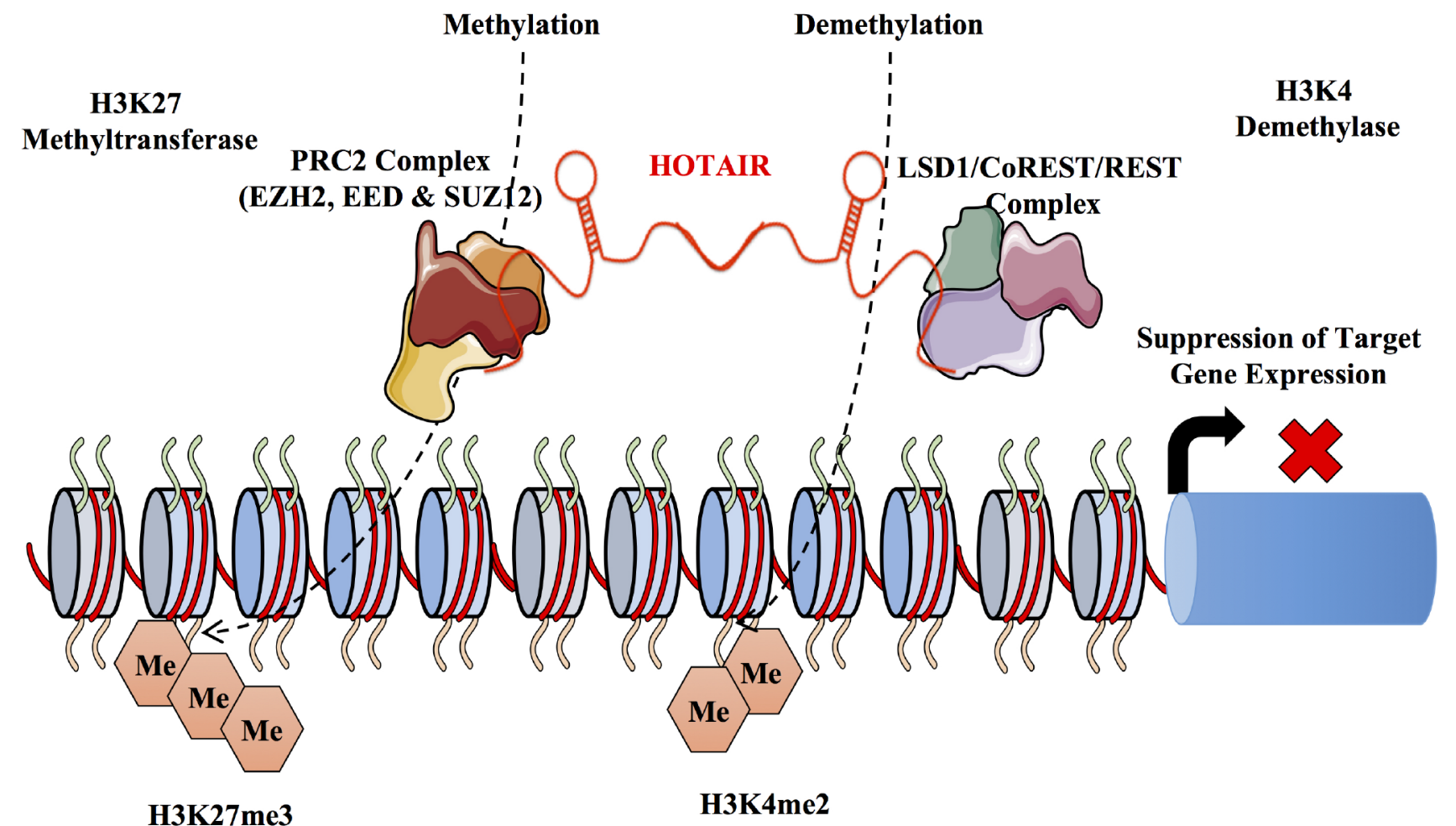

Figure 4: Mechanism of HOTAIR mediated gene silencing. The lncRNA HOTAIR is transcribed from the HOXC locus and acts in trans on the HOXD locus. It functions mainly in the recruitment and binding of the PRC2 and the LSD1 complex at the HOXD locus. HOTAIR has a dual function binding the PRC2 complex on the $5^{`}$ end and the histone lysine demethylase (LSD1) at the $3^{`}$ end. HOTAIR acts as a molecular scaffold for the protein complexes directing post translational modifications. Interestingly, while PRC2 mediates post translational modifications LSD1 inhibits post translational modifications. HOTAIR is involved in the suppression of metastasis through a series of methylation at the H3K27 and demethylation of the H3K4 histone marks. 
SRAP knockdown cells. This indicates that altering the balance between the coding and the non-coding SRA transcripts can significantly enhance breast tumorigenesis and tumour progression [207].

BCAR4 was originally identified as a breast cancer oncogene in a functional screen for genes involved in tamoxifen resistance [208, 209]. Interestingly, the lncRNA BCAR4 conferred tamoxifen resistance in a manner independent of the estrogen receptor I expression (ESR1) [209]. Additionally, ectopic expression of BCAR4 in the breast cancer cell lines MCF7 and ZR-75-1 resulted in increased cellular proliferation in estrogen free media. Similarly, BCAR4 induced a growth advantage in the presence of various antiestrogens. BCAR4 was also observed to cause anchorage independent cell growth and promotes metastasis in primary breast tumours [208]. Subsequent xenograft experiments demonstrated ZR-75-1 expressing BCAR4 proliferated more rapidly than control cells when injected in nude mice. Elevated levels of BCAR4 mRNA in patients treated with tamoxifen were associated with reduced progression free survival and clinical benefit and overall survival [210]. BCAR4 overexpressing cells correlated with increased phosphorylation of ERBB2 and ERBB3 suggesting that this pathway may be involved in driving the BCAR4 mediated resistance towards tamoxifen [210]. Interestingly, in silico analysis shows that there is a significantly high level of expression of BCAR4 in the human placenta and the oocyte while absent in other normal tissues [209]. BCAR4 may function as a suitable target for treating antiestrogen resistance in breast cancer by harnessing this tissue specific restricted expression pattern displayed by it. In terms of cell migration BCAR4 promotes metastasis which arises from the interaction of chemokines CCL21 and its receptor CCR7, activating the Rho-interacting serine/threonine kinase 21 , citron (CIT) which subsequently phosphorylates the transcription factor GLI-2 (Glioma associated oncogene homolog 2) $[211,212]$. BCAR4, thus enhances transcription of GLI2 dependent target genes in breast cancer cells through a non-canonical hedgehog-GLI pathway [213]. BCAR4 also binds to serine/threonine phosphatase regulatory subunit 10 (PSP1R10/PNUTS) and SNIP1 (Smad nuclear interacting protein 1). This interaction of phopsho-GLI2 and SNIP2 releases SNIP1 mediated inhibition of p300 dependent histone acetylation. This downstream signaling leads to binding of PNUTS to H3K18ac leading to the inhibition of PolII via activation of phosphatase PP1. [214, 215]. PP1 eventually dephosporylates RNA polymerase II Ser5 which activates the transcription of GLI2 target genes [216]. Interestingly, locked Nucleic Acids (LNA) against BCAR4 reduced lung metastasis similar to that of of MDA-MB-231 LM2 cells expressing shRNA against BCAR4 showcasing its therapeutic potential [216].

DSCAM-AS1 (Down Syndrome Cell Adhesion Molecule) is a potential oncogenic ER regulated lncRNA, that is upregulated in both ER positive and ER negative cancer compared to normal tissues [217]. Using a cohort of 947 breast cancer patients Niknafs et al. probed 58,648 lncRNAs to systematically profile lncRNA-based expression patterns. Interestingly, the authors demonstrated that like protein expression lncRNAs can stratify breast tumours by their known molecular subtypes. Using this dataset the authors further investigated oncogenic ERregulated RNAs by comparing lncRNA expression in breast cancer versus normal as well as ER positive versus ER negative comparison $[217,219]$. Using this as a cutoff $D S C A M-A S 1$ was identified as a lncRNA expressed at very high levels in breast cancer tissues, contains ER promoter binding, and exhibits the strongest estrogen induction in both MCF7 and T47D cells. Interestingly, DSCAM-AS1 is an antisense intronic lncRNA that is highly specific for luminal breast cancer. Knockdown of DSCAM-AS1 portrays features similar to the silencing of ER $\alpha$, such as reduced cell growth, increased apoptosis and the induction of EMT markers. Knockdown of DSCAM-AS1, did lead to the activation of the cell movement. However, another group showed a decrease in migration and invasiveness, which could arise from the silencing strategy used with one being long term silencing and the other transient [217, 218]. Interestingly, ER $\alpha$ expression was not altered by DSCAMAS1 silencing, suggesting DSCAM-AS1 functions downstream of ER $\alpha$. Antisense lncRNAs can regulate sense mRNAs at different levels, including transcriptional interference, RNA editing, imprinting, alternative splicing or translation, however, unlike the usual trend DSCAMAS1 does not regulate the sense mRNA DSCAM [217, 218]. DSCAM-AS1 might thus be associated in breast cancer through the process of transregulation. The unique attributes that lies in DSCAM-AS1 such as its high expression, tissue of origin specificity, and breast tumour phenotype specificity make it an important biomarker of luminal breast cancer. Further investigation needs to be carried out to understand the mechanistic functions of DSCAM-AS1.

Long Intergenic non-coding RNA for Kinase Activation (LINK-A) is a cytoplasmic lincRNA that is significantly elevated in TNBC. LINK-A has recently been observed to be critical for growth factor induced normoxic Hypoxia-inducible Factor $\alpha$ (HIF1 $\alpha$ ) signaling pathway activation [219]. LINK-A mediates Heparinbinding Epidermal-like growth factor (HB-EGF) dependent EGFR:GPNMB (Glycoprotein non-metastatic b) heterodimerization resulting in HIF $1 \alpha$ phosphorylation at Tyr565 and Ser797 by BRK (Breast tumour kinase) and LRRK2 (Leucine-rich repeat kinase 2), respectively. The phosphorylation of Tyr565 interferes with Pro564 hydroxylation leading to HIF $1 \alpha$ stabilization while on the other hand, Ser797 phosphorylation enables its interaction with p300, triggering the activation of HIF $1 \alpha$ transcriptional programs under normoxic conditions. The activation of HIF $1 \alpha$ by LINK-A alters the glycolytic 
programming in cells enhancing tumorigeneisis. Additionally, LINK-A recruits BRK to the EGFR: GPNMB heterodimer and facilitates the activation of BRK. The correlation between LINK-A and glycolysis in TNBC suggest that LINK-A may be a promising therapeutic target in TNBC [219].

\section{LncRNA BASED THERAPEUTICS}

It has been proposed that the potential of targeting lncRNAs as a therapeutic strategy may be greater than that of proteins due to their high specificity and their role in specific developmental stages. However, a number of significant drawbacks exist including their sparse availability and overall detection in cancer. This could account for why lncRNA therapeutics have not seen any breakthrough into the clinic. Furthermore, the experimental animal models used may complicate the development of lncRNA therapeutics because of the lack of conservation between species. It is however, worthwhile to mention that the potential use of IncRNA therapies is enormous as it can take advantage of the many functions of lncRNAs. As highlighted in this review lncRNAs can either act in the nucleus or in the cytoplasm and hence determining their expression pattern will be critical in designing effective strategies This can be achieved by strategies like Fluorescent In Situ Hybridization (FISH) techniques or more stringent isolation techniques through cellular nuclear and cytoplasmic fractionation [220-223]. Another important factor to consider is the potential functions of the lncRNAs and its relevance to the disease state through a correlation between the lncRNA expression levels and the disease outcomes or symptoms. Subsequently, studying lncRNA gain or loss of function studies by probing for example Fuzzy Kohonen Clustering Networks (FKCN) requires a detailed understanding of specific lncRNA function. Gene silencing strategies also need to be correctly chosen in order to silence lncRNA owing to their localization in the cytoplasm or the nuclei. In general it has been acknowledged that Anti-Sense Oligos (ASO) targeting approaches function better for nuclear lncRNA while duplex RNA approach appear to downregulate cytoplasmic lncRNA with greater efficiency [224, 225].

One such lncRNA predicted to be a therapeutic target is MALAT1. MALAT1 is a nuclear localized lncRNA and targeted inhibition of MALAT1 expression by ASOs significantly reduces tumor growth and metastasis. However, the progression of these compounds to the clinic has been limited by the identification of effective targeting strategies for delivering these ASOs within the tumor cells. Similar to MALAT1, silencing of Survival Associated Mitochondrial MelanomaSpecific Oncogenic ncRNA (SAMMSON), an oncogene which confers a proliferative advantage in melanoma, with ASO gapmers reduced clonogenicity regardless of BRAF, NRAS, or p53 status elucidating to the addiction of melanoma cells to SAMMSON expression. Critically, depletion of SAMMSON had no effect on melanocyte integrity [226]. Another lncRNA, NORAD, is upregulated in response to DNA damage and binds PUMILIO proteins PUM1 and PUM2. Ablation of NORAD using a duplex RNA approach lead to the hyperactivity of PUMILIO genes and to chromosomal instability augmenting the sensibility of NORAD depleted cells to anti-cancer agents. Lastly, Angelman's Syndrome, a severe neurodevelopment disorder is caused by a defect in expression of the maternal gene UBE3A, which encodes an E3 ubiquitin protein ligase. An antisense transcript expressed within the paternal UBE3A locus represses the expression of this allele. ASO targeting of the antisense transcript reversed the cognitive defects in a mouse model [227]. Although, these examples might not necessarily relate to breast cancer pathogenesis or treatment it does highlight the potential of targeting breast cancer specific lncRNAs with either ASOs or duplex shRNA.

\section{DIAGNOSTIC AND THERAPEUTIC POTENTIAL OF LncRNA}

LncRNAs as mentioned earlier are not only expressed in a tissue and development specific manner, but are also expressed in a cancer type specific manner and hold the potential to be used as prognostic markers. LncRNAs hold the upper hand when it comes to its application as a diagnostic because unlike mRNA, which only provides for an indirect measurement of the functional protein, lncRNAs are a functional end product in itself. Moreover, these functional mature lncRNAs can either enhance post transcriptional modifications or subsequently bind to other proteins. It may not be unrealistic to predict that in the not too distant future lncRNAs may be used as a diagnostic to aid in the pathological diagnosis and classification of certain if not all cancers. With the advent of technology and current diagnostic scenarios, simple quantitative qPCRs leading to more robust and thorough transcriptome profiles generated through RNA sequencing could be employed for the detection of lncRNAs in liquid biopsies. These non-invasive techniques could thus provide for a detailed scenario indicating any abnormal lncRNA levels in the patient. A partial overview of known lncRNAs which have been predicted to act as potential biomarkers is discussed has been discussed in Table 4.

PCA3 has been shown to be a specific biomarker for prostate cancer and act as a negative oncogenic regulator of the tumor suppressor gene PRUNE2 [34, 228]. This has led to the commercialization of a PCA3 assay to permit rapid detection of PCA3 in prostate cancer (Gen-Probe Incorporated, Progensa PCA3 Assay). Similarly, lncRNAs 


\begin{tabular}{|c|c|c|}
\hline Therapeutic Agent & Therapeutic Approach & Examples of IncRNA \\
\hline siRNA & $\begin{array}{l}\text { Double stranded RNAs. Association } \\
\text { with the RISC complex leading to } \\
\text { argonaute mediated degradation as } \\
\text { a result of perfect sequence similarity. }\end{array}$ & PANDA \\
\hline ASO & $\begin{array}{l}\text { Single Stranded oligonucleotide } \\
\text { sequence with complimentary to the } \\
\text { target lncRNA. Effective binding } \\
\text { to Secondary structure of lncRNA. } \\
\text { RNAse mediated degradation or } \\
\text { blocking of translational apparatus. }\end{array}$ & MALAT1 \\
\hline $\begin{array}{l}\text { Ribozymes and } \\
\text { deoxyribozymes }\end{array}$ & $\begin{array}{l}\text { Site specific cleaving of RNA by } \\
\text { catalytically active RNA or DNA } \\
\text { molecules. } \\
\text { Targets specific lncRNAs by short } \\
\text { sequences about } 20 \text { nucleotides long } \\
\text { flanking a central loop target. }\end{array}$ & $? ?$ \\
\hline $\begin{array}{l}\text { Nucleic Acid Aptamer } \\
\text { based }\end{array}$ & $\begin{array}{l}\text { Single-stranded RNA or DNA } \\
\text { oligonucleotides capable of } \\
\text { efficiently targeting small molecules, } \\
\text { peptides, proteins, lncRNA and live } \\
\text { cells mediated through 3D structures. }\end{array}$ & $\begin{array}{l}\text { Apatmers CD5, D57, BE9, BC4', CG3`, DB11 against } \\
\text { lncRNA PCA3 (Prostrate Cancer Antigen 3), } \\
\text { A30 against HER3 }\end{array}$ \\
\hline Small Molecule drugs & $\begin{array}{l}\text { Compounds that block the activity of } \\
\text { target lncRNAs by structure-specific } \\
\text { docking to regulate activity. }\end{array}$ & $\begin{array}{l}\text { HOTAIR (Coraline chloride hydrate,Biotin, Ellagic } \\
\text { Acid, Camptothecin }(\mathrm{S},+)\end{array}$ \\
\hline Locked Nucleic Acids & $\begin{array}{l}\text { Modified RNA nucleotide wherein } \\
\text { the ribose moiety has an extra bridge } \\
\text { linking } 2 \text { 'oxygen and } 4 \text { carbon. } \\
\text { Works by hybridization, simple base } \\
\text { pairing to DNA and RNA. }\end{array}$ & BCAR4,Miravirsen targeting miR-122 \\
\hline AntagoNATs & $\begin{array}{l}\text { Natural antisense transcripts } \\
\text { (NATs) can repress mRNA gene } \\
\text { expression at the transcriptional level. } \\
\text { Targeting NATs with single-stranded } \\
\text { oligonucleotides. Blocks interactions } \\
\text { of NATs with effector proteins or } \\
\text { by RNAse -H degradation of the } \\
\text { antisense transcript. }\end{array}$ & MALAT1 \\
\hline
\end{tabular}

in breast cancer have also emerged as front runners with potential clinical relevance. With respect to breast cancer, HOTAIR and its elevated levels in breast cancer acts as a marker for metastasis [143]. CCAT2 was also shown to be overexpressed and portrays itself as a valuable predictive marker for metastasis free survival and overall survival in patients with local metastasis of lymph node undergoing adjuvant chemotherapy [229]. Loss of GAS5 1ncRNA expression shows a strong correlation to resistance of classical chemotherapeutic agents by diminishing antiproliferative cellular responses including decreased apoptosis when cells are exposed to these agents [230]. A recent report highlighted lncRNA ASBEL as a potential novel therapeutic for TNBC. ASBEL is located antisense of B Cell translocation gene 3 (BTG3), which encodes for an anti-proliferation protein and has been reported to be downregulated in TNBC. The authors demonstrate that knockdown of ASBEL by antisense oligonucleotides re-establishes BTG3 expression resulting in decreased tumor proliferation [231]. Correlating chromatin landscape with lncRNA gene expression data, $\mathrm{Su}$ and colleagues demonstrated HOTAIR and HOTAIRM1, are 
significantly overexpressed in HER2 and TNBC subtypes, respectively [232]. Additionally, a four lncRNA signature of AK024118, BC040204, U79277 and AK000974 could be a potential biomarker in breast cancer patients [233]. Interestingly, investigations from another group showed a dual signature of 1ncRNA-BC2 and lncRNA-BC5 that were consistently up-regulated while a dual signature of lncRNA BC4 and lncRNA-BC8 that were consistently downregulated in in breast cancer samples [35]. The authors also show a signature or pattern of these lincRNA with respect to their molecular grade [35]. Highly specific and sensitive detection of circulating lncRNAs such as RP11-445H22.4 were found to be elevated in the serum of breast cancer patients [234]. A three lncRNA signature of LINC00324, PTPRG-AS1 and SNHG17, was observed in ER+ and ER-subtypes that were related to their tumour grade, with the first lncRNA significantly up-regulated and the remaining two significantly down-regulated [235]. Furthermore, a number of lincRNAs, lncRNAs, circular RNAs and have been reported earlier to be differentially expressed in breast cancer (refer to Supplementary Table 1) and could have a potential oncogenic or a tumor suppressor effect.

\section{LncRNA IN THERAPEUTIC RESISTANCE}

Despite advances in early detection and understanding the molecular basis of breast cancer biology, most patients with early stage breast cancer have recurrent disease with progression into metastasis. The heterogeneous nature of the cancer, interspersed with both populations of normal cells and cancer cells makes it a difficult task to specifically target cancer cells. Advancements in the treatment of breast cancer involves the use of cytotoxic drugs, hormonal therapy, targeted therapy and more recently immunotherapeutic agents and are aimed towards the selective administration of less toxic and effective drug treatment, based on the clinical and molecular characteristics of the tumour. In the majority of cases clinical responses are observed however, eventually resistance to these agents occurs. The identification to underlying mechanisms of resistance to these chemotherapeutic agents remains an intense focus of study. Recent efforts have been substantially aided by next-generation sequencing technologies coupled with bioinformatics [236-238]. As part of this, lncRNAs have emerged as important entities in overall drug responses due to their ability to alter the expression pattern of certain genes that might be involved in cell cycle control, apoptosis, or DNA damage and repair pathways [239-242]. We now know that lncRNA expression is widely altered in cancer and participates in various aspects of tumorigenesis through inactivation of tumour suppressors or activation of oncogenes. With respect to breast cancer, increasing reports have cited the importance of lncRNAs in breast cancer drug resistance. Breast cancer progression is mostly dependent on cues provided by estrogen levels with anti-hormone therapy (Tamoxifen) being the major therapy for ER+ breast cancers. Interestingly, a number of lncRNAs have displayed the ability to alter tamoxifen sensitivity. Table 5 shows some of the lncRNAs that are associated with cancer drug resistance and sensitivity.

Interestingly, evidence of XIST and another protein $53 \mathrm{BP} 1$, have been reported as potential predictive markers of resistance to high dose alkylating chemotherapy and can be used to identify BRCA1-like breast cancer patients. In such a treatment regimen, patients with a high XIST level and low 53BP1 levels were predictors for a poor clinical outcome compared to patients with low XIST levels and high 53BP1 protein level [243, 244]. XIST can also be used as a biomarker predicting breast cancer response to HDAC inhibitors such as abexinostat [245]. The levels of XIST in 16 breast cancer cell lines, led to their grouping into two major classes, one is a low dose sensitive group, in which the cancer stem cells were differentiated by abexinostat and a high dose sensitive group whose cancer stem cell populations were stable [245]. Curiously, in recent experiments carried out in mice low lncRNA XIST expression correlated with cisplatin hypersensitivity, but the mechanism through which this occurs remains elusive [246]. Moreover, XIST can also behave as a tumor suppressor through inhibition of AKT activation in breast cancer [247]. This is achieved mainly by the regulation of HDAC3 via the SPEN/SHARP and SMRT protein complexes. Knockdown of XIST or SPEN, enhanced HDAC3 recruitment to the promoter of $\mathrm{PH}$ domain and leucine-rich repeat phosphatase 1(PHLPP1), repressing PHLPP1 expression. PHLPP1 dephosphorylates AKT, converting the active phosphorylated form of AKT to a non-active form decreasing cell viability. Furthermore, another lncRNA, Jpx which is also involved in the tight regulation of XIST and positively regulates it, has decreased levels in breast cancer samples. Subsequently, Jpx knockdown lead to activation of AKT and increased cell viability [247]. These apparent bifunctional roles of XIST in cancer underscores the importance of understanding the molecular mechanisms underlying XIST function in determining when and where targeting XIST would be clinically beneficial. Undoubtedly, further studies will add to this list and it would be unsurprising if the number of lncRNAs does not exceed protein coding transcripts as functional biomarkers for cancer diagnosis and therapeutic sensitivity.

\section{FUTURE DIRECTIONS, PERSPECTIVES AND FINAL THOUGHTS}

Considering the fact that breast cancer is a highly heterogeneous disease centered upon a large number of variables numerous factors are required to be taken into consideration when prediciting therapeutic options. 
Table 5: LncRNAs associated with breast cancer drug resistance

\begin{tabular}{|c|c|c|c|c|}
\hline IncRNA & Drug & Breast cancer / Type & Drug Action & Reference \\
\hline HOTAIR & Tamoxifen & $\begin{array}{l}\text { Hormone receptor positive, early and } \\
\text { metastatic breast cancers }\end{array}$ & $\begin{array}{l}\text { Attaches on the hormone receptors } \\
\text { in cancer cells and blocks estrogen } \\
\text { from attaching to the receptor. }\end{array}$ & {$[277]$} \\
\hline $\begin{array}{l}\operatorname{lncRNA-} \\
\text { ATB }\end{array}$ & Trastuzumab & $\begin{array}{l}\text { Monoclonal Antibody used for breast } \\
\text { cancer that is HER } 2 \text { positive }\end{array}$ & $\begin{array}{l}\text { Works by binding to HER } 2 \text { receptor } \\
\text { and slows down cell duplication. }\end{array}$ & {$[317]$} \\
\hline BCAR4 & $\begin{array}{l}\text { Oestrogen/ } \\
\text { Lapatinib }\end{array}$ & $\begin{array}{l}\text { Used in treatment-naïve, ER+/EGFR+/ } \\
\text { HER2+ breast cancer patients and } \\
\text { patients with HER2-positive advanced } \\
\text { breast cancer that has progressed after } \\
\text { previous treatment to Trastuzumab, } \\
\text { anthracycline and taxane derived drugs. }\end{array}$ & $\begin{array}{l}\text { Dual tyrosine kinase inhibitor, that } \\
\text { interrupts HER2/neu and EGFR } \\
\text { pathways. }\end{array}$ & [318] \\
\hline BCAR4 & $\begin{array}{l}\text { Oestrogen, } \\
\text { Tamoxifen }\end{array}$ & $\begin{array}{l}\text { Hormone receptor positive, early and } \\
\text { metastatic breast cancers. }\end{array}$ & $\begin{array}{l}\text { Attaches on the hormone receptors } \\
\text { in cancer cells and blocks estrogen } \\
\text { from attaching to the receptor. }\end{array}$ & {$[209,210]$} \\
\hline HIF1A-AS2 & Paclitaxel & $\begin{array}{l}\text { Used to treat regional or locally } \\
\text { advanced breast cancers or secondary } \\
\text { breast cancer. }\end{array}$ & $\begin{array}{l}\text { Functions by inhibiting mitotic } \\
\text { spindle formation by binding } \\
\text { to beta tubulin subunits of } \\
\text { microtubules. }\end{array}$ & [319] \\
\hline AK124454 & Paclitaxel & $\begin{array}{l}\text { Used to treat regional or locally } \\
\text { advanced breast cancers or secondary } \\
\text { breast cancer. }\end{array}$ & $\begin{array}{l}\text { Functions by inhibiting mitotic } \\
\text { spindle formation by binding } \\
\text { to beta tubulin subunits of } \\
\text { microtubules. }\end{array}$ & [319] \\
\hline GAS5 & Trastuzumab & $\begin{array}{l}\text { Monoclonal Antibody used for breast } \\
\text { cancer that is HER } 2 \text { positive. }\end{array}$ & $\begin{array}{l}\text { Works by binding to HER } 2 \text { receptor } \\
\text { and slows down cell duplication. }\end{array}$ & {$[270]$} \\
\hline UCA1 & Tamoxifen & $\begin{array}{l}\text { Hormone receptor positive, early and } \\
\text { metastatic breast cancers. }\end{array}$ & $\begin{array}{l}\text { Attaches on the hormone receptors } \\
\text { in cancer cells and blocks estrogen } \\
\text { from attaching to the receptor. }\end{array}$ & {$[320,321]$} \\
\hline $\begin{array}{l}\text { lncRNA } \\
\text { RoR }\end{array}$ & Tamoxifen & $\begin{array}{l}\text { Hormone receptor positive, early and } \\
\text { metastatic breast cancers. }\end{array}$ & $\begin{array}{l}\text { Attaches on the hormone receptors } \\
\text { in cancer cells and blocks estrogen } \\
\text { from attaching to the receptor. }\end{array}$ & {$[322,323]$} \\
\hline H19 & Paclitaxel & $\begin{array}{l}\text { Used to treat regional or locally } \\
\text { advanced breast cancers or secondary } \\
\text { breast cancer. }\end{array}$ & $\begin{array}{l}\text { Functions by inhibiting mitotic } \\
\text { spindle formation by binding } \\
\text { to beta tubulin subunits of } \\
\text { microtubules. }\end{array}$ & {$[324]$} \\
\hline CCAT2 & Tamoxifen & $\begin{array}{l}\text { Hormone receptor positive, early and } \\
\text { metastatic breast cancers. }\end{array}$ & $\begin{array}{l}\text { Attaches on the hormone receptors } \\
\text { in cancer cells and blocks estrogen } \\
\text { from attaching to the receptor. }\end{array}$ & {$[325]$} \\
\hline HOTAIR & $\begin{array}{l}\text { Imatinib and } \\
\text { Lapatinib }\end{array}$ & $\begin{array}{l}\text { Imatinib- is used for CML(Chronic } \\
\text { Myelogenous Leukemia) and } \\
\text { ALL(Acute lymphocytic Leukemia) } \\
\text { and other gastrointestinal stromal } \\
\text { tumours(GIST). } \\
\text { Lapatinib- Used in treatment-naïve, } \\
\text { ER+/EGFR+/HER2+ breast cancer } \\
\text { patients and patients with HER2- } \\
\text { positive advanced breast cancer that has } \\
\text { progressed after previous treatment to } \\
\text { Trastuzumab, anthracycline and taxane } \\
\text { derived drugs. } \\
\text { Combinatorial Drug Therapy for Triple } \\
\text { Negative Breast Cancer. }\end{array}$ & $\begin{array}{l}\text { Imatinib-Specific inhibitor of } \\
\text { tyrosine kinase by occupying the } \\
\text { tyrosine kinase active site and } \\
\text { decreasing the activity(abl(Abelson } \\
\text { proto-oncogene, c-kit and } \\
\text { PDGFR(platelet derived growth } \\
\text { factor receptor)). } \\
\text { Dual tyrosine kinase inhibitor, that } \\
\text { interrupts HER2/neu and EGFR } \\
\text { pathways. }\end{array}$ & {$[326]$} \\
\hline
\end{tabular}


LINP1 is overexpressed in triple negative breast cancer. LINP1 enhances repair of the DNA double strand breaks by serving as LINP1 Radiation and scaffold liking to Ku-80 and DNAPKcs

LINP1 regulated by $\mathrm{p} 53$ and EGFR receptor signalling.
Involved in NHEJ pathway

Blocking of LINP1 leads to increased sensitivity of tumour cells
The recent advances in sequencing technology has played a large part in prolonging the survival rates of breast cancer patients but their overall prognosis to date remains limited. Quicker and rapid means of prognosis and diagnosis of breast cancer patients would allow for accurate and efficient therapeutic regimes. The evidence cited in this review point towards an important role of lncRNAs in breast cancer biology and mammary development. LncRNA, being tissue specific and developmental stage specific can be harnessed to serve as potential biomarkers or aid in the prognosis of breast cancer, Additionally, with all but a few exceptions the majority of evidence presented to date on lncRNAs involvement breast cancer is largely based on correlative data where a number of inconsistencies have been reported primarily due to analysis pipelines

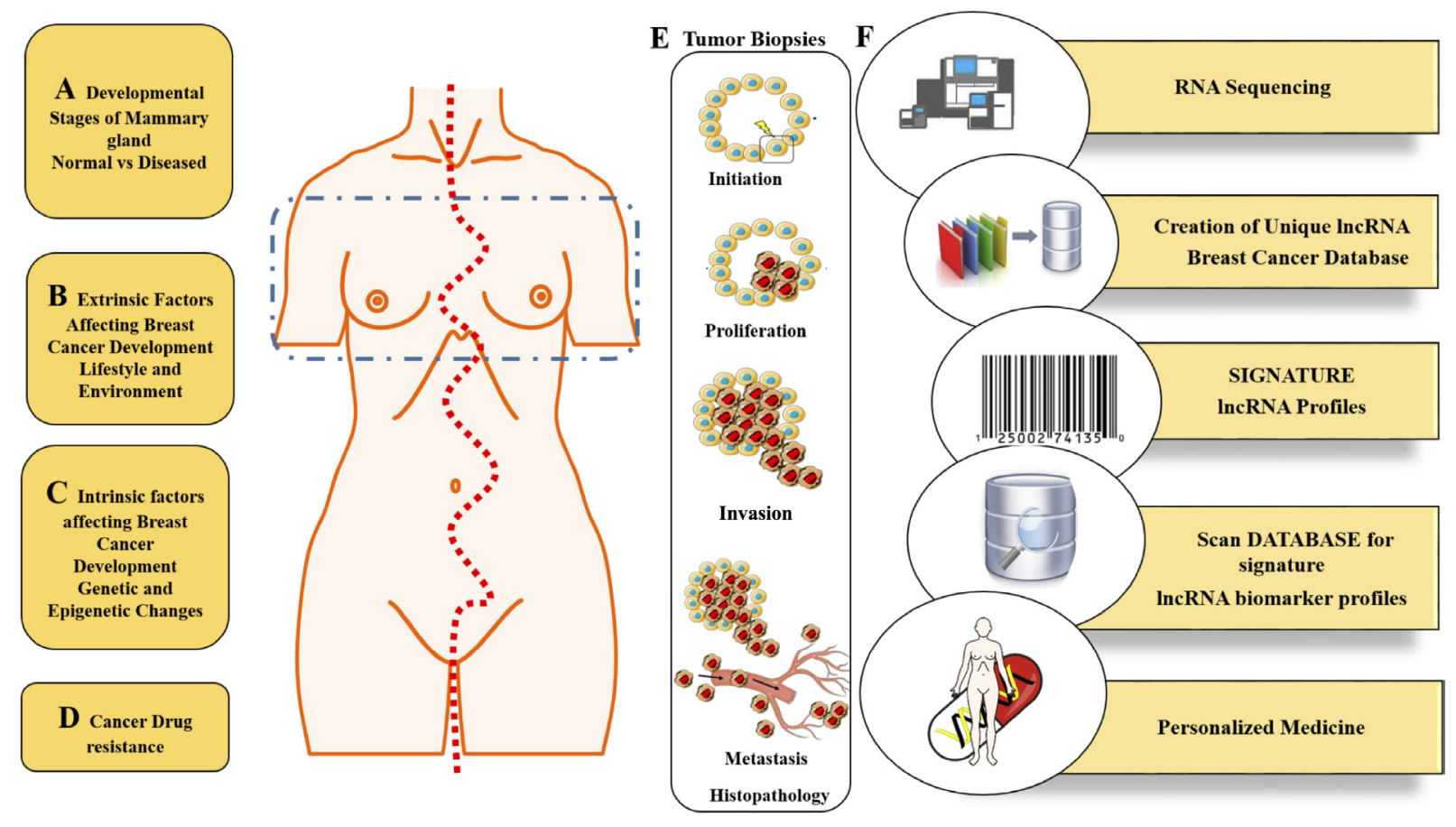

Figure 5: Translational implication of IncRNAs in Breast cancer: What the future holds! Schematic of the diagnostic and therapeutic potential of IncRNAs in breast cancer. Presently, breast cancer treatment remains limited by a multitude of factors including genetic heterogeneity and intrinsic or acquired resistance. In these settings breast cancer would greatly benefit from early diagnostic methods to treat breast cancer in its pre-invasive state prior to metastasis. Utilizing lncRNA expression patterns and signatures would ideally aid in this regard. Developmental stages of a normal cell versus a cancer cell can be easily tracked by cataloging the transcriptome profiles of lncRNAs (A). Similarly, patients having cancer due to extrinsic factors such as environment and lifestyle as well as intrinsic factors such as epigenetic, heredity and genetic predisposition to the disease would have a unique lncRNA profile (B and C). Additionally, alterations in the expression pattern of lncRNAs following relapse to targeted therapies may be utilized to understand the mechanism of resistance. (D). Linking the lncRNA profiles to the different developmental stages as well the grade/stage of the cancer could help us understand better the cancer scenario and the drug regiment to be administered. A multi-pronged approach including pathological analysis of tumor biopsies along with transcriptomic profiling of both protein coding and non-coding RNA may be beneficial (E). Finally, with the advent of technologies and high throughput strategies such as RNA sequencing and transcriptome profiling it would be advantageous to create a unique lncRNA Breast Cancer Database. With the help of statistical and bioinformatics analysis a fine line could be drawn between diseased and normal states through a signature lncRNA profile. In the future, efficient invasive and non-invasive techniques to diagnose breast cancer status will undoubtedly require a comprehensive lncRNA profile of patients providing another cog linking individual disease with verified therapeutic options (F). 
used for normalization, a diverse set of technology platforms used, the reaction methodologies adapted for sample processing or simply the differences in the sample types, cell lines and tissues analyzed. These discrepancies require follow-up analyses but importantly an international standardization of protocols in respect to tissue collection, processing and data interpretation is required. Only with this standardization can we gain a comprehensive molecular understanding of the roles of lncRNA in respect to breast cancer.

LncRNAs have nudged their way into the being an important and impacting entity triggering one or more hallmarks of cancer. In this sense, lncRNAs have been reported as important regulators of gene expression and have a broad spectrum of functions including the activation of a diverse set of signaling pathways. The list of such dysregulated lncRNAs in associated disease conditions and normal physiological conditions is on the rise. However, lncRNA research may still be considered in its infancy and is far from being fully recognized due to technical limitations such as its low expression and its fragility as long RNA molecules. A combination of computational analysis along with robust methodologies such as RIP, RAP, CHIRP, CHART, iCLIP and PAR-CLIP followed by sequencing and mass-spectrometry will allow for a detailed understanding of the lncRNA function and mechanism of action in cancer. Keeping in mind the aggressive nature of breast cancer it is important to unearth biomarkers with high sensitivity and specificity to detect breast cancer at an earlier stage. Diagnostic biomarkers that can predict the different stages of breast cancer or yield clinical viable genetic signatures are critical in determining effective treatment therapy options (Figure 5A-5C). Furthermore, resistance to chemotherapy and lncRNAs that are differentially regulated as a result of resistance can suggest alternate clinical treatment approaches (Figure 5D). Identifying lncRNAs as non-invasive biomarkers, that can be robustly detected in liquid biopsies could revolutionize the way breast cancer is detected. The grading of breast cancer through the gold standard procedures of tumor biopsies followed by histological grading can be subjected to transcriptome profiling could reveal important lncRNA signature profiles (Figure 5E, 5F). While lncRNAs still pose a difficulty with cellular targeting, strategies of enhanced delivery using nanotechnology, or exosomes coupled with targeted drug delivery could be beneficial. While this review only covers lncRNAs in breast cancer development, we should not neglect the other non-coding species like miRNAs, piRNAs, tRNA derivatives, snoRNAs and T-UCRs. Unearthing the many functions of noncoding RNAs in cancer development delves into the genomic complexity of cancer and further highlights the extensive interplay between various genetic elements in the cells.

\section{ACKNOWLEDGMENTS}

This work was in part supported by the by the National Research Foundation Singapore and the Singapore Ministry of Education under its Research Centers of Excellence initiative, Koninklijke Philips N.V and the Ministry of Education Academic Research Fund Tier 1 grants (T1-2013 Sep-10) and (T1-2014 Oct -08).

\section{Note}

Callouts for the below references are included into Supplementary Table 1. [249, 250, 251, 252, 253, 254, 255, 256, $257,258,259,260,261,262,263,264,265,266,267,268,269$, $270,271,272,273,274,275,276,277,278,279,280,281,282$, $283,284,285,286,287,288,289,290,291,292,293,294,295$, $296,297,298,299,300,301,302,303,304,305,306,307,308$, $309,310,311,312,313,314,315,316,317,318]$.

\section{CONFLICTS OF INTEREST}

None.

\section{REFERENCES}

1. Siegel RL, Miller KD, Jemal A. Cancer statistics, 2016. CA Cancer J Clin. 2016; 66:7-30. https://doi.org/10.3322/ caac. 21332.

2. Fernández Y, Cueva J, Palomo AG, Ramos M, de Juan A, Calvo L, García-Mata J, García-Teijido P, Peláez I, GarcíaEstévez L. Novel therapeutic approaches to the treatment of metastatic breast cancer. Cancer Treat Rev. 2010; 36:33-42. https://doi.org/10.1016/j.ctrv.2009.10.001.

3. Gray J, Druker B. Genomics: the breast cancer landscape. Nature. 2012; 486:328-29. https://doi.org/10.1038/486328a.

4. Ban KA, Godellas CV. Epidemiology of breast cancer. Surg Oncol Clin N Am. 2014; 23:409-22. https://doi. org/10.1016/j.soc.2014.03.011.

5. Macias H, Hinck L. Mammary gland development. Wiley Interdiscip Rev Dev Biol. 2012; 1:533-57. https://doi. org/10.1002/wdev.35.

6. Rijnkels M, Kabotyanski E, Montazer-Torbati MB, Hue Beauvais C, Vassetzky Y, Rosen JM, Devinoy E. The epigenetic landscape of mammary gland development and functional differentiation. J Mammary Gland Biol Neoplasia. 2010; 15:85-100. https://doi.org/10.1007/ s10911-010-9170-4.

7. Watson CJ, Khaled WT. Mammary development in the embryo and adult: a journey of morphogenesis and commitment. Development. 2008; 135:995-1003. https:// doi.org/10.1242/dev.005439. 
8. Bertone P, Stolc V, Royce TE, Rozowsky JS, Urban AE, Zhu X, Rinn JL, Tongprasit W, Samanta M, Weissman S, Gerstein M, Snyder M. Global identification of human transcribed sequences with genome tiling arrays. Science. 2004; 306:2242-6. https://doi.org/10.1126/science.1103388.

9. Mattick JS, Rinn JL. Discovery and annotation of long noncoding RNAs. Nat Struct Mol Biol. 2015; 22:5-7. https:// doi.org/10.1038/nsmb.2942.

10. Mercer TR, Gerhardt DJ, Dinger ME, Crawford J, Trapnell C, Jeddeloh JA, Mattick JS, Rinn JL. Targeted RNA sequencing reveals the deep complexity of the human transcriptome. Nat Biotechnol. 2011; 30:99-104. https://doi.org/10.1038/ nbt.2024.

11. ENCODE Project Consortium. The ENCODE (ENCyclopedia Of DNA Elements) Project. Science. 2004; 306:636-40. https://doi.org/10.1126/science.1105136.

12. Forrest AR, Kawaji H, Rehli M, Baillie JK, de Hoon MJ, Haberle V, Lassmann T, Kulakovskiy IV, Lizio M, Itoh M, Andersson R, Mungall CJ, Meehan TF, et al, and FANTOM Consortium and the RIKEN PMI and CLST (DGT). A promoter-level mammalian expression atlas. Nature. 2014; 507:462-70. https://doi.org/10.1038/nature13182.

13. Lonsdale J, Thomas J, Salvatore M, Phillips R, Lo E, Shad S, Hasz R, Walters G, Garcia F, Young N, Foster B, Moser $\mathrm{M}$, Karasik E, et al, and GTEx Consortium. The GenotypeTissue Expression (GTEx) project. Nat Genet. 2013; 45:580 85. https://doi.org/10.1038/ng.2653.

14. Harrow J, Frankish A, Gonzalez JM, Tapanari E, Diekhans M, Kokocinski F, Aken BL, Barrell D, Zadissa A, Searle S, Barnes I, Bignell A, Boychenko V, et al. GENCODE: the reference human genome annotation for The ENCODE Project. Genome Res. 2012; 22:1760-74. https://doi. org/10.1101/gr.135350.111.

15. Esteller M. Non-coding RNAs in human disease. Nat Rev Genet. 2011; 12:861-74. https://doi.org/10.1038/nrg3074.

16. Diederichs S, Bartsch L, Berkmann JC, Fröse K, Heitmann J, Hoppe C, Iggena D, Jazmati D, Karschnia P, Linsenmeier M, Maulhardt T, Möhrmann L, Morstein J, et al. The dark matter of the cancer genome: aberrations in regulatory elements, untranslated regions, splice sites, non-coding RNA and synonymous mutations. EMBO Mol Med. 2016; 8:442-57. https://doi.org/10.15252/emmm.201506055.

17. Mattick JS, Makunin IV. Non-coding RNA. Hum Mol Genet. 2006: 15:R17-29. https://doi.org/10.1093/hmg/dd1046.

18. Li L, Liu Y. Diverse small non-coding RNAs in RNA interference pathways. Methods Mol Biol. 2011; 764:169-82. https://doi.org/10.1007/978-1-61779-188-8_11.

19. Lo PK, Wolfson B, Zhou X, Duru N, Gernapudi R, Zhou Q. Noncoding RNAs in breast cancer. Brief Funct Genomics. 2016; 15:200-21. https://doi.org/10.1093/bfgp/elv055.

20. Kutter C, Svoboda P. miRNA, siRNA, piRNA: knowns of the unknown. RNA Biol. 2008; 5:181-88. https://doi. org/10.4161/rna.7227.
21. Costa FF. Non-coding RNAs, epigenetics and complexity. Gene. 2008; 410:9-17. https://doi.org/10.1016/j. gene.2007.12.008.

22. Richard JL, Ogawa Y. Understanding the Complex Circuitry of lncRNAs at the X-inactivation Center and Its Implications in Disease Conditions. Curr Top Microbiol Immunol. 2016; 394:1-27.

23. Gutschner T, Diederichs S. The hallmarks of cancer: a long non-coding RNA point of view. RNA Biol. 2012; 9:703-19. https://doi.org/10.4161/rna.20481.

24. Sana J, Faltejskova P, Svoboda M, Slaby O. Novel classes of non-coding RNAs and cancer. J Transl Med. 2012; 10:103. https://doi.org/10.1186/1479-5876-10-103.

25. Derrien T, Johnson R, Bussotti G, Tanzer A, Djebali S, Tilgner H, Guernec G, Martin D, Merkel A, Knowles DG, Lagarde J, Veeravalli L, Ruan X, et al. The GENCODE v7 catalog of human long noncoding RNAs: analysis of their gene structure, evolution, and expression. Genome Res. 2012; 22:1775-89. https://doi.org/10.1101/gr.132159.111.

26. Wang KC, Chang HY. Molecular mechanisms of long noncoding RNAs. Mol Cell. 2011; 43:904-14. https://doi. org/10.1016/j.molcel.2011.08.018.

27. Berretta J, Morillon A. Pervasive transcription constitutes a new level of eukaryotic genome regulation. EMBO Rep. 2009; 10:973-82. https://doi.org/10.1038/embor.2009.181.

28. Ponting CP, Oliver PL, Reik W. Evolution and functions of long noncoding RNAs. Cell. 2009; 136:629-41. https://doi. org/10.1016/j.cell.2009.02.006.

29. Wilusz JE, Sunwoo H, Spector DL. Long noncoding RNAs: functional surprises from the RNA world. Genes Dev. 2009; 23:1494-504. https://doi.org/10.1101/gad.1800909.

30. Zhang J, Zhang P, Wang L, Piao HL, Ma L. Long noncoding RNA HOTAIR in carcinogenesis and metastasis. Acta Biochim Biophys Sin (Shanghai). 2014; 46:1-5. https://doi. org/10.1093/abbs/gmt117.

31. Yoshimoto R, Mayeda A, Yoshida M, Nakagawa S. MALAT1 long non-coding RNA in cancer. Biochim Biophys Acta. 2016; 1859:192-99. https://doi.org/10.1016/j. bbagrm.2015.09.012.

32. Gong WJ, Yin JY, Li XP, Fang C, Xiao D, Zhang W, Zhou $\mathrm{HH}$, Li X, Liu ZQ. Association of well-characterized lung cancer lncRNA polymorphisms with lung cancer susceptibility and platinum-based chemotherapy response. Tumour Biol. 2016; 37:8349-58. https://doi.org/10.1007/ s13277-015-4497-5.

33. Monnier P, Martinet C, Pontis J, Stancheva I, Ait-Si-Ali S, Dandolo L. H19 lncRNA controls gene expression of the Imprinted Gene Network by recruiting MBD1. Proc Natl Acad Sci USA. 2013; 110:20693-98. https://doi.org/10.1073/ pnas. 1310201110.

34. Hessels D, Schalken JA. The use of PCA 3 in the diagnosis of prostate cancer. Nat Rev Urol. 2009; 6:255-61. https://doi. org/10.1038/nrurol.2009.40. 
35. Ding X, Zhu L, Ji T, Zhang X, Wang F, Gan S, Zhao M, Yang H. Long intergenic non-coding RNAs (LincRNAs) identified by RNA-seq in breast cancer. PLoS One. 2014; 9:e103270. https://doi.org/10.1371/journal.pone.0103270.

36. Xu N, Wang F, Lv M, Cheng L. Microarray expression profile analysis of long non-coding RNAs in human breast cancer: a study of Chinese women. Biomed Pharmacother. 2015; 69:221-27. https://doi.org/10.1016/j.biopha.2014.12.002.

37. Reiche K, Kasack K, Schreiber S, Lüders T, Due EU, Naume B, Riis M, Kristensen VN, Horn F, Børresen-Dale AL, Hackermüller J, Baumbusch LO. Long non-coding RNAs differentially expressed between normal versus primary breast tumor tissues disclose converse changes to breast cancer-related protein-coding genes. PLoS One. 2014; 9:e106076. https://doi.org/10.1371/journal.pone.0106076.

38. Yang F, Lyu S, Dong S, Liu Y, Zhang X, Wang O. Expression profile analysis of long noncoding RNA in HER-2-enriched subtype breast cancer by next-generation sequencing and bioinformatics. OncoTargets Ther. 2016; 9:761-72. https:// doi.org/10.2147/OTT.S97664.

39. Shen X, Xie B, Ma Z, Yu W, Wang W, Xu D, Yan X, Chen B, Yu L, Li J, Chen X, Ding K, Cao F. Identification of novel long non-coding RNAs in triple-negative breast cancer. Oncotarget. 2015; 6:21730-39. https://doi.org/10.18632/ oncotarget.4419.

40. Guttman M, Rinn JL. Modular regulatory principles of large non-coding RNAs. Nature. 2012; 482:339-46. https://doi. org/10.1038/nature10887.

41. Morris KV, Mattick JS. The rise of regulatory RNA. Nat Rev Genet. 2014; 15:423-37. https://doi.org/10.1038/nrg3722.

42. Rinn JL, Chang HY. Genome regulation by long noncoding RNAs. Annu Rev Biochem. 2012; 81:145-66. https://doi. org/10.1146/annurev-biochem-051410-092902.

43. Sleutels F, Zwart R, Barlow DP. The non-coding Air RNA is required for silencing autosomal imprinted genes. Nature. 2002; 415:810-13. https://doi.org/10.1038/415810a.

44. Pandey RR, Mondal T, Mohammad F, Enroth S, Redrup L, Komorowski J, Nagano T, Mancini-Dinardo D, Kanduri C. Kcnq1ot1 antisense noncoding RNA mediates lineagespecific transcriptional silencing through chromatinlevel regulation. Mol Cell. 2008; 32:232-46. https://doi. org/10.1016/j.molcel.2008.08.022.

45. Guttman M, Amit I, Garber M, French C, Lin MF, Feldser D, Huarte M, Zuk O, Carey BW, Cassady JP, Cabili MN, Jaenisch R, Mikkelsen TS, et al. Chromatin signature reveals over a thousand highly conserved large non-coding RNAs in mammals. Nature. 2009; 458:223-27. https://doi. org/10.1038/nature07672.

46. Quinn JJ, Chang HY. Unique features of long non-coding RNA biogenesis and function. Nat Rev Genet. 2016; 17:4762. https://doi.org/10.1038/nrg.2015.10.

47. Yang L. Splicing noncoding RNAs from the inside out. Wiley Interdiscip Rev RNA. 2015; 6:651-60. https://doi. org/10.1002/wrna.1307.
48. De Santa F, Barozzi I, Mietton F, Ghisletti S, Polletti S, Tusi BK, Muller H, Ragoussis J, Wei CL, Natoli G. A large fraction of extragenic RNA pol II transcription sites overlap enhancers. PLoS Biol. 2010; 8:e1000384. https://doi. org/10.1371/journal.pbio.1000384.

49. Sati S, Ghosh S, Jain V, Scaria V, Sengupta S. Genome-wide analysis reveals distinct patterns of epigenetic features in long non-coding RNA loci. Nucleic Acids Res. 2012; 40:1001831. https://doi.org/10.1093/nar/gks776.

50. Li R, Zhu H, Luo Y. Understanding the functions of long noncoding RNAs through their higher-order structures. Int J Mol Sci. 2016; 17:E702. https://doi.org/10.3390/ijms17050702.

51. Bazzini AA, Johnstone TG, Christiano R, Mackowiak SD, Obermayer B, Fleming ES, Vejnar CE, Lee MT, Rajewsky N, Walther TC, Giraldez AJ. Identification of small ORFs in vertebrates using ribosome footprinting and evolutionary conservation. EMBO J. 2014; 33:981-93. https://doi. org/10.1002/embj.201488411.

52. Guttman M, Russell P, Ingolia NT, Weissman JS, Lander ES. Ribosome profiling provides evidence that large noncoding RNAs do not encode proteins. Cell. 2013; 154:240-51. https://doi.org/10.1016/j.cell.2013.06.009.

53. Ingolia NT, Brar GA, Stern-Ginossar N, Harris MS, Talhouarne GJ, Jackson SE, Wills MR, Weissman JS. Ribosome profiling reveals pervasive translation outside of annotated protein-coding genes. Cell Reports. 2014; 8:136579. https://doi.org/10.1016/j.celrep.2014.07.045.

54. Ingolia NT. Ribosome Footprint Profiling of Translation throughout the Genome. Cell. 2016; 165:22-33. https://doi. org/10.1016/j.cell.2016.02.066.

55. Ingolia NT, Lareau LF, Weissman JS. Ribosome profiling of mouse embryonic stem cells reveals the complexity and dynamics of mammalian proteomes. Cell. 2011; 147:789802. https://doi.org/10.1016/j.cell.2011.10.002.

56. Ruiz-Orera J, Messeguer X, Subirana JA, Alba MM. Long non-coding RNAs as a source of new peptides. eLife. 2014; 3:e03523. https://doi.org/10.7554/eLife.03523.

57. Mercer TR, Mattick JS. Structure and function of long noncoding RNAs in epigenetic regulation. Nat Struct Mol Biol. 2013; 20:300-07. https://doi.org/10.1038/nsmb.2480.

58. Dinger ME, Gascoigne DK, Mattick JS. The evolution of RNAs with multiple functions. Biochimie. 2011; 93:201318. https://doi.org/10.1016/j.biochi.2011.07.018.

59. Jeck WR, Sorrentino JA, Wang K, Slevin MK, Burd CE, Liu J, Marzluff WF, Sharpless NE. Circular RNAs are abundant, conserved, and associated with ALU repeats. RNA. 2013; 19:141-57. https://doi.org/10.1261/rna.035667.112.

60. Barrett SP, Salzman J. Circular RNAs: analysis, expression and potential functions. Development. 2016; 143:1838-47. https://doi.org/10.1242/dev.128074.

61. Meng X, Li X, Zhang P, Wang J, Zhou Y, Chen M. Circular RNA: an emerging key player in RNA world. Brief Bioinform. 2017; 18:547-57. https://doi.org/10.1093/bib/ bbw045. 
62. Vicens Q, Westhof E. Biogenesis of Circular RNAs. Cell. 2014; 159:13-14. https://doi.org/10.1016/j.cell.2014.09.005.

63. Starke S, Jost I, Rossbach O, Schneider T, Schreiner S, Hung LH, Bindereif A. Exon circularization requires canonical splice signals. Cell Reports. 2015; 10:103-11. https://doi. org/10.1016/j.celrep.2014.12.002.

64. Zhang XO, Wang HB, Zhang Y, Lu X, Chen LL, Yang L. Complementary sequence-mediated exon circularization. Cell. 2014; 159:134-47. https://doi.org/10.1016/j. cell.2014.09.001.

65. Kelly S, Greenman C, Cook PR, Papantonis A. Exon Skipping Is Correlated with Exon Circularization. J Mol Biol. 2015; 427:2414-17. https://doi.org/10.1016/j. jmb.2015.02.018.

66. Li Z, Huang C, Bao C, Chen L, Lin M, Wang X, Zhong G, Yu B, Hu W, Dai L, Zhu P, Chang Z, Wu Q, et al. Exon-intron circular RNAs regulate transcription in the nucleus. Nat Struct Mol Biol. 2015; 22:256-64. https://doi.org/10.1038/ nsmb.2959.

67. Li Z, Huang C, Bao C, Chen L, Lin M, Wang X, Zhong G, Yu B, Hu W, Dai L, Zhu P, Chang Z, Wu Q, et al. Corrigendum: Exon-intron circular RNAs regulate transcription in the nucleus. Nat Struct Mol Biol. 2017; 24:194. https://doi. org/10.1038/nsmb0217-194a.

68. Monat C, Quiroga C, Laroche-Johnston F, Cousineau B. The L1.LtrB intron from Lactococcus lactis excises as circles in vivo: insights into the group II intron circularization pathway. RNA. 2015; 21:1286-93. https://doi.org/10.1261/ rna.046367.114.

69. Han P, Chang CP. Long non-coding RNA and Chromatin Remodeling. RNA Biol. 2015; 6286:1094-1098. https://doi. org/10.1080/15476286.2015.1063770.

70. Lau E. Non-coding RNA: zooming in on lncRNA functions. Nat Rev Genet. 2014; 15:574-75. https://doi.org/10.1038/ $\operatorname{nrg} 3795$.

71. Ye N, Wang B, Quan ZF, Cao SJ, Wen XT, Huang Y, Huang XB, Wu R, Ma XP, Yan QG. Functional roles of long non-coding RNA in human breast cancer. Asian Pac J Cancer Prev. 2014; 15:5993-97. https://doi.org/10.7314/ APJCP.2014.15.15.5993.

72. van Heesch S, van Iterson M, Jacobi J, Boymans S, Essers PB, de Bruijn E, Hao W, MacInnes AW, Cuppen E, Simonis M. Extensive localization of long noncoding RNAs to the cytosol and mono- and polyribosomal complexes. Genome Biol. 2014; 15:R6. https://doi.org/10.1186/gb-2014-15-1-r6.

73. van Leeuwen S, Mikkers H. Long non-coding RNAs: guardians of development. Differentiation. 2010; 80:175-83. https://doi.org/10.1016/j.diff.2010.07.003.

74. Nugoli M, Chuchana P, Vendrell J, Orsetti B, Ursule L, Nguyen C, Birnbaum D, Douzery EJ, Cohen P, Theillet C. Genetic variability in MCF-7 sublines: evidence of rapid genomic and RNA expression profile modifications. BMC Cancer. 2003; 3:13. https://doi.org/10.1186/1471-2407-3-13.
75. Du Z, Fei T, Verhaak RG, Su Z, Zhang Y, Brown M, Chen Y, Liu XS. Integrative genomic analyses reveal clinically relevant long noncoding RNAs in human cancer. Nat Struct Mol Biol. 2013; 20:908-13. https://doi.org/10.1038/ nsmb. 2591.

76. Perez DS, Hoage TR, Pritchett JR, Ducharme-Smith AL, Halling ML, Ganapathiraju SC, Streng PS, Smith DI. Long, abundantly expressed non-coding transcripts are altered in cancer. Hum Mol Genet. 2008; 17:642-55. https://doi. org $/ 10.1093 / \mathrm{hmg} / \mathrm{ddm} 336$.

77. Tano K, Akimitsu N. Long non-coding RNAs in cancer progression. Front Genet. 2012; 3:219. https://doi. org/10.3389/fgene.2012.00219.

78. Vikram R, Ramachandran R, Abdul KS. Functional significance of long non-coding RNAs in breast cancer. Breast Cancer. 2014; 21:515-21. https://doi.org/10.1007/ s12282-014-0554-y.

79. Malek E, Jagannathan S, Driscoll JJ. Correlation of long noncoding RNA expression with metastasis, drug resistance and clinical outcome in cancer. Oncotarget. 2014; 5:8027-38. https://doi.org/10.18632/oncotarget.2469.

80. Hu P, Chu J, Wu Y, Sun L, Lv X, Zhu Y, Li J, Guo Q, Gong C, Liu B, Su S. NBAT1 suppresses breast cancer metastasis by regulating DKK1 via PRC2. Oncotarget. 2015; 6:32410 25. https://doi.org/10.18632/oncotarget.5609.

81. Deng R, Liu B, Wang Y, Yan F, Hu S, Wang H, Wang T, Li B, Deng X, Xiang S, Yang Y, Zhang J. High expression of the newly found long noncoding RNA Z38 promotes cell proliferation and oncogenic activity in breast cancer. Spanish (International Sort). J Cancer. 2016; 7:576-86. https://doi. org/10.7150/jca.13117.

82. Tu ZQ, Li RJ, Mei JZ, Li XH. Down-regulation of long non-coding RNA GAS5 is associated with the prognosis of hepatocellular carcinoma. Int J Clin Exp Pathol. 2014; 7:4303-09.

83. Hu D, Su C, Jiang M, Shen Y, Shi A, Zhao F, Chen R, Shen Z, Bao J, Tang W. Fenofibrate inhibited pancreatic cancer cells proliferation via activation of p53 mediated by upregulation of LncRNA MEG3. Biochem Biophys Res Commun. 2016; 471:290-95. https://doi.org/10.1016/j.bbrc.2016.01.169.

84. Chunharojrith P, Nakayama Y, Jiang X, Kery RE, Ma J, De La Hoz Ulloa CS, Zhang X, Zhou Y, Klibanski A. Tumor suppression by MEG3 lncRNA in a human pituitary tumor derived cell line. Mol Cell Endocrinol. 2015; 416:27-35. https://doi.org/10.1016/j.mce.2015.08.018.

85. Tripathi V, Shen Z, Chakraborty A, Giri S, Freier SM, Wu X, Zhang Y, Gorospe M, Prasanth SG, Lal A, Prasanth KV. Long noncoding RNA MALAT1 controls cell cycle progression by regulating the expression of oncogenic transcription factor B-MYB. PLoS Genet. 2013; 9:e1003368. https://doi. org/10.1371/journal.pgen.1003368.

86. Mahmoudi S, Henriksson S, Corcoran M, Méndez-Vidal C, Wiman KG, Farnebo M. Wrap53, a natural p53 antisense transcript required for p53 induction upon DNA damage. 
Mol Cell. 2009; 33:462-71. https://doi.org/10.1016/j. molcel.2009.01.028.

87. Mahmoudi S, Henriksson S, Corcoran M, Méndez-Vidal C, Wiman KG, Farnebo M. Wrap53, a Natural p53 Antisense Transcript Required for p53 Induction upon DNA Damage. Mol Cell. 2016; 64:1009. https://doi.org/10.1016/j. molcel.2016.11.027.

88. Mahmoudi S, Henriksson S, Farnebo L, Roberg K, Farnebo M. WRAP53 promotes cancer cell survival and is a potential target for cancer therapy. Cell Death Dis. 2011; 2:e114. https://doi.org/10.1038/cddis.2010.90.

89. Huarte M, Guttman M, Feldser D, Garber M, Koziol MJ, Kenzelmann-Broz D, Khalil AM, Zuk O, Amit I, Rabani M, Attardi LD, Regev A, Lander ES, et al. A large intergenic noncoding RNA induced by p53 mediates global gene repression in the p53 response. Cell. 2010; 142:409-19. https://doi.org/10.1016/j.cell.2010.06.040.

90. Sang Y, Tang J, Li S, Li L, Tang X, Cheng C, Luo Y, Qian $X$, Deng LM, Liu L, Lv XB. LncRNA PANDAR regulates the G1/S transition of breast cancer cells by suppressing p16(INK4A) expression. Sci Rep. 2016; 6:22366. https://doi. org/10.1038/srep22366.

91. Chen YM, Liu Y, Wei HY, Lv KZ, Fu PF. Large intergenic non-coding RNA-ROR reverses gemcitabineinduced autophagy and apoptosis in breast cancer cells. Oncotarget. 2016; 7:59604-59617. https://doi.org/10.18632/ oncotarget. 10730 .

92. Dugimont T, Montpellier C, Adriaenssens E, Lottin S, Dumont L, Iotsova V, Lagrou C, Stéhelin D, Coll J, Curgy JJ. The H19 TATA-less promoter is efficiently repressed by wild-type tumor suppressor gene product $\mathrm{p} 53$. Oncogene. 1998; 16:2395-401. https://doi.org/10.1038/sj.onc.1201742.

93. Liu Q, Huang J, Zhou N, Zhang Z, Zhang A, Lu Z, Wu F, Mo YY. LncRNA loc285194 is a p53-regulated tumor suppressor. Nucleic Acids Res. 2013; 41:4976-87. https:// doi.org/10.1093/nar/gkt182.

94. Pasmant E, Sabbagh A, Vidaud M, Bièche I. ANRIL, a long, noncoding RNA, is an unexpected major hotspot in GWAS. FASEB J. 2011; 25:444-48. https://doi.org/10.1096/ fj.10-172452.

95. Cheetham SW, Gruhl F, Mattick JS, Dinger ME. Long noncoding RNAs and the genetics of cancer. Br J Cancer. 2013; 108:2419-25. https://doi.org/10.1038/bjc.2013.233.

96. Kotake Y, Nakagawa T, Kitagawa K, Suzuki S, Liu N, Kitagawa M, Xiong Y. Long non-coding RNA ANRIL is required for the PRC2 recruitment to and silencing of p15(INK4B) tumor suppressor gene. Oncogene. 2011; 30:1956-62. https://doi.org/10.1038/onc.2010.568.

97. Wiseman BS, Werb Z. Stromal effects on mammary gland development and breast cancer. Science. 2002; 296:1046-49. https://doi.org/10.1126/science.1067431.

98. Visvader JE. Keeping abreast of the mammary epithelial hierarchy and breast tumorigenesis. Genes Dev. 2009; 23:2563-77. https://doi.org/10.1101/gad.1849509.
99. Hassiotou F, Geddes D. Anatomy of the human mammary gland: current status of knowledge. Clin Anat. 2013; 26:2948. https://doi.org/10.1002/ca.22165.

100. Sternlicht MD. Key stages in mammary gland development: the cues that regulate ductal branching morphogenesis. Breast Cancer Res. 2006; 8:201. https://doi.org/10.1186/bcr1368.

101. Tiede B, Kang Y. From milk to malignancy: the role of mammary stem cells in development, pregnancy and breast cancer. Cell Res. 2011; 21:245-57. https://doi.org/10.1038/ cr.2011.11.

102. Clarkson RW, Watson CJ. Microarray analysis of the involution switch. J Mammary Gland Biol Neoplasia. 2003; 8:309-19. https://doi.org/10.1023/B:JOMG.0000010031.53310.92.

103. Schedin P. Pregnancy-associated breast cancer and metastasis. Nat Rev Cancer. 2006; 6:281-91. https://doi. org/10.1038/nrc1839.

104. Schedin P, Mitrenga T, McDaniel S, Kaeck M, Mammary EC. Mammary ECM composition and function are altered by reproductive state. Mol Carcinog. 2004; 41:207-20. https:// doi.org/10.1002/mc.20058.

105. Song J, Sapi E, Brown W, Nilsen J, Tartaro K, Kacinski BM, Craft J, Naftolin F, Mor G. Roles of Fas and Fas ligand during mammary gland remodeling. J Clin Invest. 2000; 106:1209-20. https://doi.org/10.1172/JCI10411.

106. Bemis LT, Schedin P. Reproductive state of rat mammary gland stroma modulates human breast cancer cell migration and invasion. Cancer Res. 2000; 60:3414-18. http://www. ncbi.nlm.nih.gov/htbin-post/Entrez/query?db=m\&form $=6 \&$ dopt=r\&uid=10910049>.

107. McDaniel SM, Rumer KK, Biroc SL, Metz RP, Singh M, Porter W, Schedin P. Remodeling of the mammary microenvironment after lactation promotes breast tumor cell metastasis. Am J Pathol. 2006; 168:608-20. https://doi. org/10.2353/ajpath.2006.050677.

108. Keen J. Breast Cancer - Focusing Tumor Microenvironment, Stem cells and Metastasis. 2011; 3-20. https://doi. org/10.5772/1747.

109. Layde PM, Webster LA, Baughman AL, Wingo PA, Rubin GL, Ory HW, and Cancer and Steroid Hormone Study Group. The independent associations of parity, age at first full term pregnancy, and duration of breastfeeding with the risk of breast cancer. J Clin Epidemiol. 1989; 42:963-73. https:// doi.org/10.1016/0895-4356(89)90161-3.

110. Henson DE, Tarone RE, Nsouli H. Lobular involution: the physiological prevention of breast cancer. J Natl Cancer Inst. 2006; 98:1589-90. https://doi.org/10.1093/jnci/djj454.

111. Schonfeld SJ, Pfeiffer RM, Lacey JV Jr, Berrington de González A, Doody MM, Greenlee RT, Park Y, Schairer C, Schatzkin A, Sigurdson AJ, Hartge P, Visvanathan K. Hormone-related risk factors and postmenopausal breast cancer among nulliparous versus parous women: an aggregated study. Am J Epidemiol. 2011; 173:509-17. https://doi.org/10.1093/aje/kwq404. 
112. Venkitaraman R. Lobular neoplasia of the breast. Breast J. 2010; 16:519-28. https://doi.org/10.1111/j.1524-4741.2010.00971.x.

113. Toriola AT, Vääräsmäki M, Lehtinen $M$, Zeleniuch-Jacquotte A, Lundin E, Rodgers KG, Lakso HA, Chen T, Schock H, Hallmans G, Pukkala E, Toniolo P, Grankvist K, et al. Determinants of maternal sex steroids during the first half of pregnancy. Obstet Gynecol. 2011; 118:1029-36. https://doi. org/10.1097/AOG.0b013e3182342b7f.

114. Troisi R, Hoover RN, Thadhani R, Hsieh CC, Sluss P, Ballard-Barbash R, Potischman N. Maternal, prenatal and perinatal characteristics and first trimester maternal serum hormone concentrations. Br J Cancer. 2008; 99:1161-64. https://doi.org/10.1038/sj.bjc.6604639.

115. Carlsen SM, Jacobsen G, Vanky E. Mid-pregnancy androgen levels are negatively associated with breastfeeding. Acta Obstet Gynecol Scand. 2010; 89:87-94. https://doi. org/10.3109/00016340903318006.

116. Zeleniuch-Jacquotte A, Afanasyeva Y, Kaaks R, Rinaldi S, Scarmo S, Liu M, Arslan AA, Toniolo P, Shore RE, Koenig KL. Premenopausal serum androgens and breast cancer risk: a nested case-control study. Breast Cancer Res. 2012; 14:R32. https://doi.org/10.1186/bcr3117.

117. Hankinson SE, Eliassen AH. Circulating sex steroids and breast cancer risk in premenopausal women. Horm Cancer. 2010; 1:2-10. https://doi.org/10.1007/s12672-009-0003-0.

118. Brown SB, Hankinson SE. Endogenous estrogens and the risk of breast, endometrial, and ovarian cancers. Steroids. 2015; 99:8-10. https://doi.org/10.1016/j.steroids.2014.12.013.

119. Tworoger SS, Hankinson SE. Prolactin and breast cancer risk. Cancer Lett. 2006; 243:160-69. https://doi.org/10.1016/j. canlet.2006.01.032.

120. Tworoger SS, Eliassen AH, Sluss P, Hankinson SE. A prospective study of plasma prolactin concentrations and risk of premenopausal and postmenopausal breast cancer. J Clin Oncol. 2007; 25:1482-88. https://doi.org/10.1200/ JCO.2006.07.6356.

121. Sørlie T. Molecular portraits of breast cancer: tumour subtypes as distinct disease entities. Eur J Cancer. 2004; 40:2667-75. https://doi.org/10.1016/j.ejca.2004.08.021.

122. Denkert C, Loibl S, Müller BM, Eidtmann H, Schmitt WD, Eiermann W, Gerber B, Tesch H, Hilfrich J, Huober J, Fehm T, Barinoff J, Jackisch C, et al. Ki67 levels as predictive and prognostic parameters in pretherapeutic breast cancer core biopsies: a translational investigation in the neoadjuvant GeparTrio trial. Ann Oncol. 2013; 24:2786-93. https://doi. org/10.1093/annonc/mdt350.

123. Dent R, Trudeau M, Pritchard KI, Hanna WM, Kahn HK, Sawka CA, Lickley LA, Rawlinson E, Sun P, Narod SA. Triple-negative breast cancer: clinical features and patterns of recurrence. Clin Cancer Res. 2007; 13:4429-34. https:// doi.org/10.1158/1078-0432.CCR-06-3045.

124. Foulkes WD, Smith IE, Reis-Filho JS. Triple-negative breast cancer. N Engl J Med. 2010; 363:1938-48. https://doi. org/10.1056/NEJMra1001389.
125. Radisky DC, Hartmann LC. Mammary involution and breast cancer risk: transgenic models and clinical studies. J Mammary Gland Biol Neoplasia. 2009; 14:181-91. https:// doi.org/10.1007/s10911-009-9123-y.

126. Prat A, Perou CM. Mammary development meets cancer genomics. Nat Med. 2009; 15:842-44. https://doi. org/10.1038/nm0809-842.

127. Lim E, Vaillant F, Wu D, Forrest NC, Pal B, Hart AH, Asselin-Labat ML, Gyorki DE, Ward T, Partanen A, Feleppa F, Huschtscha LI, Thorne HJ, et al, and kConFab. Aberrant luminal progenitors as the candidate target population for basal tumor development in BRCA1 mutation carriers. Nat Med. 2009; 15:907-13. https://doi.org/10.1038/nm.2000.

128. Gjorevski N, Nelson CM. Integrated morphodynamic signalling of the mammary gland. Nat Rev Mol Cell Biol. 2011; 12:581-93. https://doi.org/10.1038/nrm3168.

129. Hennighausen L, Robinson GW. Information networks in the mammary gland. Nat Rev Mol Cell Biol. 2005; 6:715-25. https://doi.org/10.1038/nrm1714.

130. Siegel PM, Muller WJ. Transcription factor regulatory networks in mammary epithelial development and tumorigenesis. Oncogene. 2010; 29:2753-59. https://doi. org/10.1038/onc.2010.43.

131. Avril-Sassen S, Goldstein LD, Stingl J, Blenkiron C, Le Quesne J, Spiteri I, Karagavriilidou K, Watson CJ, Tavaré S, Miska EA, Caldas C. Characterisation of microRNA expression in post-natal mouse mammary gland development. BMC Genomics. 2009; 10:548. https://doi. org/10.1186/1471-2164-10-548.

132. Tong C, Chen Q, Zhao L, Ma J, Ibeagha-Awemu EM, Zhao X. Identification and characterization of long intergenic noncoding RNAs in bovine mammary glands. BMC Genomics. 2017; 18:468. https://doi.org/10.1186/ s12864-017-3858-4.

133. Standaert L, Adriaens C, Radaelli E, Van Keymeulen A, Blanpain C, Hirose T, Nakagawa S, Marine JC. The long noncoding RNA Neat1 is required for mammary gland development and lactation. RNA. 2014; 20:1844-49. https:// doi.org/10.1261/rna.047332.114.

134. Adriaenssens E, Lottin S, Dugimont T, Fauquette W, Coll J, Dupouy JP, Boilly B, Curgy JJ. Steroid hormones modulate H19 gene expression in both mammary gland and uterus. Oncogene. 1999; 18:4460-73. https://doi.org/10.1038/ sj.onc. 1202819 .

135. Lanz RB, Chua SS, Barron N, Söder BM, DeMayo F, O'Malley BW. Steroid receptor RNA activator stimulates proliferation as well as apoptosis in vivo. Mol Cell Biol. 2003; 23:7163-76. https://doi.org/10.1128/ MCB.23.20.7163-7176.2003.

136. Murphy LC, Simon SL, Parkes A, Leygue E, Dotzlaw H, Snell L, Troup S, Adeyinka A, Watson PH. Altered expression of estrogen receptor coregulators during human breast tumorigenesis. Cancer Res. 2000; 60:6266-71. 
137. Askarian-Amiri ME, Crawford J, French JD, Smart CE, Smith MA, Clark MB, Ru K, Mercer TR, Thompson ER, Lakhani SR, Vargas AC, Campbell IG, Brown MA, et al. SNORD-host RNA Zfas1 is a regulator of mammary development and a potential marker for breast cancer. RNA. 2011; 17:878-91. https://doi.org/10.1261/rna.2528811.

138. Ginger MR, Gonzalez-Rimbau MF, Gay JP, Rosen JM. Persistent changes in gene expression induced by estrogen and progesterone in the rat mammary gland. Mol Endocrinol. 2001; 15:1993-2009. https://doi.org/10.1210/ mend.15.11.0724.

139. Hansji H, Leung EY, Baguley BC, Finlay GJ, CameronSmith D, Figueiredo VC, Askarian-Amiri ME. ZFAS1: a long noncoding RNA associated with ribosomes in breast cancer cells. Biol Direct. 2016; 11:62. https://doi.org/10.1186/ s13062-016-0165-y.

140. Ginger MR, Shore AN, Contreras A, Rijnkels M, Miller J, Gonzalez-Rimbau MF, Rosen JM. A noncoding RNA is a potential marker of cell fate during mammary gland development. Proc Natl Acad Sci USA. 2006; 103:5781-86. https://doi.org/10.1073/pnas.0600745103.

141. Shore AN, Kabotyanski EB, Roarty K, Smith MA, Zhang Y, Creighton CJ, Dinger ME, Rosen JM. Pregnancy-induced noncoding RNA (PINC) associates with polycomb repressive complex 2 and regulates mammary epithelial differentiation. PLoS Genet. 2012; 8:e1002840. https://doi.org/10.1371/ journal.pgen.1002840.

142. Chen F, Capecchi MR. Paralogous mouse Hox genes, Hoxa9, Hoxb9, and Hoxd9, function together to control development of the mammary gland in response to pregnancy. Proc Natl Acad Sci USA. 1999; 96:541-46. https://doi.org/10.1073/ pnas.96.2.541.

143. Gupta RA, Shah N, Wang KC, Kim J, Horlings HM, Wong DJ, Tsai MC, Hung T, Argani P, Rinn JL, Wang Y, Brzoska P, Kong B, et al. Long non-coding RNA HOTAIR reprograms chromatin state to promote cancer metastasis. Nature. 2010; 464:1071-76. https://doi.org/10.1038/nature08975.

144. Bhan A, Mandal SS. LncRNA HOTAIR: A master regulator of chromatin dynamics and cancer. Biochim Biophys Acta. 2015; 1856:151-64. https://doi.org/10.1016/j.bbcan.2015.07.001.

145. Li L, Liu B, Wapinski OL, Tsai MC, Qu K, Zhang J, Carlson JC, Lin M, Fang F, Gupta RA, Helms JA, Chang HY. Targeted disruption of Hotair leads to homeotic transformation and gene derepression. Cell Reports. 2013; 5:3-12. https://doi.org/10.1016/j.celrep.2013.09.003.

146. Amândio AR, Necsulea A, Joye E, Mascrez B, Duboule D. Hotair Is Dispensible for Mouse Development. PLoS Genet. 2016; 12:e1006232. https://doi.org/10.1371/journal. pgen. 1006232 .

147. Tao S, He H, Chen Q. Estradiol induces HOTAIR levels via GPER-mediated miR-148a inhibition in breast cancer. J Transl Med. 2015; 13:131. https://doi.org/10.1186/ s12967-015-0489-x.
148. Wang Y, Dong J, Li D, Lai L, Siwko S, Li Y, Liu M. Lgr4 regulates mammary gland development and stem cell activity through the pluripotency transcription factor Sox2. Stem Cells. 2013; 31:1921-31. https://doi.org/10.1002/stem.1438.

149. Askarian-Amiri ME, Seyfoddin V, Smart CE, Wang J, Kim JE, Hansji H, Baguley BC, Finlay GJ, Leung EY. Emerging role of long non-coding RNA SOX2OT in SOX2 regulation in breast cancer. PLoS One. 2014; 9:e102140. https://doi. org/10.1371/journal.pone.0102140.

150. Russo J, Santucci-Pereira J, de Cicco RL, Sheriff F, Russo PA, Peri S, Slifker M, Ross E, Mello ML, Vidal BC, Belitskaya-Lévy I, Arslan A, Zeleniuch-Jacquotte A, et al. Pregnancy-induced chromatin remodeling in the breast of postmenopausal women. Int J Cancer. 2012; 131:1059-70. https://doi.org/10.1002/ijc.27323.

151. Wutz A. Xist function: bridging chromatin and stem cells. Trends Genet. 2007; 23:457-64. https://doi.org/10.1016/j. tig.2007.07.004.

152. Niu N, Mercado-Uribe I, Liu J. Dedifferentiation into blastomere-like cancer stem cells via formation of polyploid giant cancer cells. Oncogene. 2017; 36:4887-900. https://doi. org/10.1038/onc.2017.72.

153. Plath K, Mlynarczyk-Evans S, Nusinow DA, Panning B. Xist RNA and the mechanism of X chromosome inactivation. Annu Rev Genet. 2002; 36:233-78. https://doi.org/10.1146/ annurev.genet.36.042902.092433.

154. Pageau GJ, Hall LL, Ganesan S, Livingston DM, Lawrence JB. The disappearing Barr body in breast and ovarian cancers. Nat Rev Cancer. 2007; 7:628-33. https://doi.org/10.1038/ nrc2172.

155. Di Oto E, Monti V, Cucchi MC, Masetti R, Varga Z, Foschini MP. X chromosome gain in male breast cancer. Hum Pathol. 2015; 46:1908-12. https://doi.org/10.1016/j. humpath.2015.08.008.

156. Weakley SM, Wang H, Yao Q, Chen C. Expression and function of a large non-coding RNA gene XIST in human cancer. World J Surg. 2011; 35:1751-56. https://doi. org/10.1007/s00268-010-0951-0.

157. Kawakami T, Zhang C, Taniguchi T, Kim CJ, Okada Y, Sugihara H, Hattori T, Reeve AE, Ogawa O, Okamoto $\mathrm{K}$. Characterization of loss-of-inactive $\mathrm{X}$ in Klinefelter syndrome and female-derived cancer cells. Oncogene. 2004; 23:6163-69. https://doi.org/10.1038/sj.onc.1207808.

158. Pageau GJ, Lawrence JB. BRCA1 foci in normal S-phase nuclei are linked to interphase centromeres and replication of pericentric heterochromatin. J Cell Biol. 2006; 175:693-701. https://doi.org/10.1083/jcb.200602055.

159. Pageau GJ, Hall LL, Lawrence JB. BRCA1 does not paint the inactive $\mathrm{X}$ to localize XIST RNA but may contribute to broad changes in cancer that impact XIST and Xi heterochromatin. J Cell Biochem. 2007; 100:835-50. https://doi.org/10.1002/ jcb. 21188 .

160. Ganesan S, Silver DP, Greenberg RA, Avni D, Drapkin R, Miron A, Mok SC, Randrianarison V, Brodie S, Salstrom J, 
Rasmussen TP, Klimke A, Marrese C, et al. BRCA1 supports XIST RNA concentration on the inactive $\mathrm{X}$ chromosome. Cell. 2002; 111:393-405. https://doi.org/10.1016/ S0092-8674(02)01052-8.

161. Ganesan S, Silver DP, Drapkin R, Greenberg R, Feunteun $\mathrm{J}$, Livingston DM. Association of BRCA1 with the inactive X chromosome and XIST RNA. Philos Trans R Soc Lond B Biol Sci. 2004; 359:123-28. https://doi.org/10.1098/ rstb.2003.1371.

162. Stone C, McCabe N, Ashworth A. X-chromosome inactivation: X marks the spot for BRCA1. Curr Biol. 2003; 13:R63-64. https://doi.org/10.1016/S0960-9822(02)01430-6.

163. Sirchia SM, Ramoscelli L, Grati FR, Barbera F, Coradini D, Rossella F, Porta G, Lesma E, Ruggeri A, Radice P, Simoni G, Miozzo M. Loss of the inactive X chromosome and replication of the active $\mathrm{X}$ in BRCA1-defective and wild-type breast cancer cells. Cancer Res. 2005; 65:2139-46. https:// doi.org/10.1158/0008-5472.CAN-04-3465.

164. Richardson AL, Wang ZC, De Nicolo A, Lu X, Brown M, Miron A, Liao X, Iglehart JD, Livingston DM, Ganesan S. X chromosomal abnormalities in basal-like human breast cancer. Cancer Cell. 2006; 9:121-32. https://doi. org/10.1016/j.ccr.2006.01.013.

165. Xiao C, Sharp JA, Kawahara M, Davalos AR, Difilippantonio MJ, Hu Y, Li W, Cao L, Buetow K, Ried T, Chadwick BP, Deng CX, Panning B. The XIST noncoding RNA functions independently of BRCA1 in X inactivation. Cell. 2007; 128:977-89. https://doi.org/10.1016/j.cell.2007.01.034.

166. Vincent-Salomon A, Ganem-Elbaz C, Manié E, Raynal V, Sastre-Garau X, Stoppa-Lyonnet D, Stern MH, Heard E. $X$ inactive-specific transcript RNA coating and genetic instability of the X chromosome in BRCA1 breast tumors. Cancer Res. 2007; 67:5134-40. https://doi.org/10.1158/00085472.CAN-07-0465.

167. Silver DP, Dimitrov SD, Feunteun J, Gelman R, Drapkin R, Lu SD, Shestakova E, Velmurugan S, Denunzio N, Dragomir S, Mar J, Liu X, Rottenberg S, et al. Further evidence for BRCA1 communication with the inactive $\mathrm{X}$ chromosome. Cell. 2007; 128:991-1002. https://doi.org/10.1016/j. cell.2007.02.025.

168. Penny GD, Kay GF, Sheardown SA, Rastan S, Brockdorff N. Requirement for Xist in X chromosome inactivation. Nature. 1996; 379:131-37. https://doi.org/10.1038/379131a0.

169. Heard E, Clerc P, Avner P. X-chromosome inactivation in mammals. Annu Rev Genet. 1997; 31:571-610. https://doi. org/10.1146/annurev.genet.31.1.571.

170. Briggs SF, Reijo Pera RA. X chromosome inactivation: recent advances and a look forward. Curr Opin Genet Dev. 2014; 28:78-82. https://doi.org/10.1016/j.gde.2014.09.010.

171. Wutz A, Gribnau J. X inactivation Xplained. Curr Opin Genet Dev. 2007; 17:387-93. https://doi.org/10.1016/j. gde.2007.08.001.

172. Wutz A. Gene silencing in X-chromosome inactivation: advances in understanding facultative heterochromatin formation. Nat Rev Genet. 2011; 12:542-53. https://doi. org/10.1038/nrg3035.

173. Chu C, Zhang QC, da Rocha ST, Flynn RA, Bharadwaj M, Calabrese JM, Magnuson T, Heard E, Chang HY. Systematic discovery of Xist RNA binding proteins. Cell. 2015; 161:404-16. https://doi.org/10.1016/j.cell.2015.03.025.

174. McHugh CA, Chen CK, Chow A, Surka CF, Tran C, McDonel P, Pandya-Jones A, Blanco M, Burghard C, Moradian A, Sweredoski MJ, Shishkin AA, Su J, et al. The Xist lncRNA interacts directly with SHARP to silence transcription through HDAC3. Nature. 2015; 521:232-36. https://doi.org/10.1038/nature14443.

175. Sunwoo H, Wu JY, Lee JT. The Xist RNA-PRC2 complex at 20-nm resolution reveals a low Xist stoichiometry and suggests a hit-and-run mechanism in mouse cells. Proc Natl Acad Sci U S A. 2015;.112:E4216-25.

176. Zhao J, Ohsumi TK, Kung JT, Ogawa Y, Grau DJ, Sarma K, Song JJ, Kingston RE, Borowsky M, Lee JT. Genomewide identification of polycomb-associated RNAs by RIPseq. Mol Cell. 2010; 40:939-53. https://doi.org/10.1016/j. molcel.2010.12.011.

177. Zhao J, Sun BK, Erwin JA, Song JJ, Lee JT. Polycomb proteins targeted by a short repeat RNA to the mouse $\mathrm{X}$ chromosome. Science. 2008; 322:750-56. https://doi. org/10.1126/science.1163045.

178. Moindrot B, Brockdorff N. RNA binding proteins implicated in Xist-mediated chromosome silencing. Semin Cell Dev Biol. 2016; 56:58-70. https://doi.org/10.1016/j. semcdb.2016.01.029.

179. Minajigi A, Froberg J, Wei C, Sunwoo H, Kesner B, Colognori D, Lessing D, Payer B, Boukhali M, Haas W, Lee JT. Chromosomes. A comprehensive Xist interactome reveals cohesin repulsion and an RNA-directed chromosome conformation. Science. 2015;.349(6245).

180. Monfort A, Di Minin G, Postlmayr A, Freimann R, Arieti F, Thore S, Wutz A. Identification of Spen as a crucial factor for Xist function through forward genetic screening in haploid embryonic stem cells. Cell Reports. 2015; 12:554-61. https:// doi.org/10.1016/j.celrep.2015.06.067.

181. Patil DP, Chen CK, Pickering BF, Chow A, Jackson C, Guttman M, Jaffrey SR. m(6)A RNA methylation promotes XIST-mediated transcriptional repression. Nature. 2016; 537:369-73. https://doi.org/10.1038/nature19342.

182. Gorski JJ, Savage KI, Mulligan JM, McDade SS, Blayney JK, Ge Z, Harkin DP. Profiling of the BRCA1 transcriptome through microarray and ChIP-chip analysis. Nucleic Acids Res. 2011; 39:9536-48. https://doi.org/10.1093/nar/gkr679.

183. Meraldi P, Honda R, Nigg EA. Aurora kinases link chromosome segregation and cell division to cancer susceptibility. Curr Opin Genet Dev. 2004; 14:29-36. https:// doi.org/10.1016/j.gde.2003.11.006.

184. Hall LL, Byron M, Pageau G, Lawrence JB. AURKBmediated effects on chromatin regulate binding versus release 
of XIST RNA to the inactive chromosome. J Cell Biol. 2009; 186:491-507. https://doi.org/10.1083/jcb.200811143.

185. Chaligné R, Popova T, Mendoza-Parra MA, Saleem MA, Gentien D, Ban K, Piolot T, Leroy O, Mariani O, Gronemeyer H, Vincent-Salomon A, Stern MH, Heard E. The inactive X chromosome is epigenetically unstable and transcriptionally labile in breast cancer. Genome Res. 2015; 25:488-503. https://doi.org/10.1101/gr.185926.114.

186. Rinn JL, Kertesz M, Wang JK, Squazzo SL, Xu X, Brugmann SA, Goodnough LH, Helms JA, Farnham PJ, Segal E, Chang HY. Functional demarcation of active and silent chromatin domains in human HOX loci by noncoding RNAs. Cell. 2007; 129:1311-23. https://doi.org/10.1016/j. cell.2007.05.022.

187. Woo CJ, Kingston RE. HOTAIR lifts noncoding RNAs to new levels. Cell. 2007; 129:1257-59. https://doi. org/10.1016/j.cell.2007.06.014.

188. Teschendorff AE, Lee SH, Jones A, Fiegl H, Kalwa M, Wagner W, Chindera K, Evans I, Dubeau L, Orjalo A, Horlings HM, Niederreiter L, Kaser A, et al. HOTAIR and its surrogate DNA methylation signature indicate carboplatin resistance in ovarian cancer. Genome Med. 2015; 7:108. https://doi.org/10.1186/s13073-015-0233-4.

189. Chisholm KM, Wan Y, Li R, Montgomery KD, Chang HY, West RB. Detection of long non-coding RNA in archival tissue: correlation with polycomb protein expression in primary and metastatic breast carcinoma. PLoS One. 2012; 7:e47998. https://doi.org/10.1371/journal.pone.0047998.

190. Endo H, Shiroki T, Nakagawa T, Yokoyama M, Tamai K, Yamanami H, Fujiya T, Sato I, Yamaguchi K, Tanaka N, Iijima K, Shimosegawa T, Sugamura K, Satoh K. Enhanced expression of long non-coding RNA HOTAIR is associated with the development of gastric cancer. PLoS One. 2013; 8:e77070. https://doi.org/10.1371/journal.pone.0077070.

191. Li H, An J, Wu M, Zheng Q, Gui X, Li T, Pu H, Lu D. LncRNA HOTAIR promotes human liver cancer stem cell malignant growth through downregulation of SETD2. Oncotarget. 2015; 6:27847-64. https://doi.org/10.18632/ oncotarget.4443.

192. Ono H, Motoi N, Nagano H, Miyauchi E, Ushijima M, Matsuura M, Okumura S, Nishio M, Hirose T, Inase N, Ishikawa Y. Long noncoding RNA HOTAIR is relevant to cellular proliferation, invasiveness, and clinical relapse in small-cell lung cancer. Cancer Med. 2014; 3:632-42. https:// doi.org/10.1002/cam4.220.

193. Sørensen KP, Thomassen M, Tan Q, Bak M, Cold S, Burton M, Larsen MJ, Kruse TA. Long non-coding RNA HOTAIR is an independent prognostic marker of metastasis in estrogen receptor-positive primary breast cancer. Breast Cancer Res Treat. 2013; 142:529-36. https://doi.org/10.1007/ s10549-013-2776-7.

194. Lu L, Zhu G, Zhang C, Deng Q, Katsaros D, Mayne ST, Risch HA, Mu L, Canuto EM, Gregori G, Benedetto C, Yu H. Association of large noncoding RNA HOTAIR expression and its downstream intergenic $\mathrm{CpG}$ island methylation with survival in breast cancer. Breast Cancer Res Treat. 2012; 136:875-83. https://doi.org/10.1007/s10549-012-2314-z.

195. Chen K, Huang YH, Chen JL. Understanding and targeting cancer stem cells: therapeutic implications and challenges. Acta Pharmacol Sin. 2013; 34:732-40. https://doi. org/10.1038/aps.2013.27.

196. Clevers H. The cancer stem cell: premises, promises and challenges. Nat Med. 2011; 17:313-19. https://doi. org/10.1038/nm.2304.

197. Deng J, Yang M, Jiang R, An N, Wang X, Liu B. Long non-coding RNA HOTAIR regulates the proliferation, selfrenewal capacity, tumor formation and migration of the cancer stem- like cell (CSC) subpopulation enriched from breast cancer cells. PLoS One. 2017; 12:e0170860. https:// doi.org/10.1371/journal.pone.0170860.

198. Xu ZY, Yu QM, Du YA, Yang LT, Dong RZ, Huang L, Yu PF, Cheng XD. Knockdown of long non-coding RNA HOTAIR suppresses tumor invasion and reverses epithelialmesenchymal transition in gastric cancer. Int J Biol Sci. 2013; 9:587-97. https://doi.org/10.7150/ijbs.6339.

199. Peinado H, Ballestar E, Esteller M, Cano A. Snail mediates E-cadherin repression by the recruitment of the $\operatorname{Sin} 3 \mathrm{~A} /$ histone deacetylase 1 (HDAC1)/HDAC2 complex. Mol Cell Biol. 2004; 24:306-19. https://doi.org/10.1128/ MCB.24.1.306-319.2004.

200. Lee S, Hong S, Kim S, Kang S. Ataxin-1 occupies the promoter region of E-cadherin in vivo and activates CtBP2repressed promoter. Biochim Biophys Acta. 2011; 1813:71322. https://doi.org/10.1016/j.bbamcr.2011.01.035.

201. Jeanes A, Gottardi CJ, Yap AS. Cadherins and cancer: how does cadherin dysfunction promote tumor progression? Oncogene. 2008; 27:6920-29. https://doi.org/10.1038/ onc.2008.343.

202. Cowin P, Rowlands TM, Hatsell SJ. Cadherins and catenins in breast cancer. Curr Opin Cell Biol. 2005; 17:499-508. https://doi.org/10.1016/j.ceb.2005.08.014.

203. Peinado H, Portillo F, Cano A. Transcriptional regulation of cadherins during development and carcinogenesis. Int J Dev Biol. 2004; 48:365-75. https://doi.org/10.1387/ ijdb.041794hp.

204. Bhan A, Hussain I, Ansari KI, Bobzean SA, Perrotti LI, Mandal SS. Bisphenol-A and diethylstilbestrol exposure induces the expression of breast cancer associated long noncoding RNA HOTAIR in vitro and in vivo. J Steroid Biochem Mol Biol. 2014; 141:160-70. https://doi. org/10.1016/j.jsbmb.2014.02.002.

205. Zhang M, Wu WB, Wang ZW, Wang XH. IncRNA NEAT1 is closely related with progression of breast cancer via promoting proliferation and EMT. Eur Rev Med Pharmacol Sci. 2017; 21:1020-26. https://www.ncbi.nlm.nih.gov/ pubmed/28338194.

206. Li W, Zhang Z, Liu X, Cheng X, Zhang Y, Han X, Zhang Y, Liu S, Yang J, Xu B, He L, Sun L, Liang J, Shang Y. 
The FOXN3-NEAT1-SIN3A repressor complex promotes progression of hormonally responsive breast cancer. J Clin Invest. 2017; 127:3421-40. https://doi.org/10.1172/ JCI94233.

207. Cooper C, Guo J, Yan Y, Chooniedass-Kothari S, Hube F, Hamedani MK, Murphy LC, Myal Y, Leygue E. Increasing the relative expression of endogenous non-coding Steroid Receptor RNA Activator (SRA) in human breast cancer cells using modified oligonucleotides. Nucleic Acids Res. 2009; 37:4518-31. https://doi.org/10.1093/nar/gkp441.

208. Meijer D, van Agthoven T, Bosma PT, Nooter K, Dorssers LC. Functional screen for genes responsible for tamoxifen resistance in human breast cancer cells. Mol Cancer Res. 2006; 4:379-86. https://doi.org/10.1158/1541-7786. MCR-05-0156.

209. Godinho M, Meijer D, Setyono-Han B, Dorssers LC, van Agthoven T. Characterization of BCAR4, a novel oncogene causing endocrine resistance in human breast cancer cells. J Cell Physiol. 2011; 226:1741-49. https://doi.org/10.1002/ jcp.22503.

210. Godinho MF, Sieuwerts AM, Look MP, Meijer D, Foekens JA, Dorssers LC, van Agthoven T. Relevance of BCAR4 in tamoxifen resistance and tumour aggressiveness of human breast cancer. Br J Cancer. 2010; 103:1284-91. https://doi. org/10.1038/sj.bjc.6605884.

211. Li F, Zou Z, Suo N, Zhang Z, Wan F, Zhong G, Qu Y, Ntaka KS, Tian H. CCL21/CCR7 axis activating chemotaxis accompanied with epithelial-mesenchymal transition in human breast carcinoma. Med Oncol. 2014; 31:180. https:// doi.org/10.1007/s12032-014-0180-8.

212. Gai M, Camera P, Dema A, Bianchi F, Berto G, Scarpa E, Germena G, Di Cunto F. Citron kinase controls abscission through RhoA and anillin. Mol Biol Cell. 2011; 22:3768-78. https://doi.org/10.1091/mbc.E10-12-0952.

213. Rubin LL, de Sauvage FJ. Targeting the Hedgehog pathway in cancer. Nat Rev Drug Discov. 2006; 5:1026-33. https:// doi.org/10.1038/nrd2086.

214. Fujii M, Lyakh LA, Bracken CP, Fukuoka J, Hayakawa M, Tsukiyama T, Soll SJ, Harris M, Rocha S, Roche KC, Tominaga S, Jen J, Perkins ND, et al. SNIP1 is a candidate modifier of the transcriptional activity of c-Myc on E boxdependent target genes. Mol Cell. 2006; 24:771-83. https:// doi.org/10.1016/j.molcel.2006.11.006.

215. Ciurciu A, Duncalf L, Jonchere V, Lansdale N, Vasieva O, Glenday P, Rudenko A, Vissi E, Cobbe N, Alphey L, Bennett D. PNUTS/PP1 regulates RNAPII-mediated gene expression and is necessary for developmental growth. PLoS Genet. 2013; 9:e1003885. https://doi.org/10.1371/journal. pgen. 1003885.

216. Xing Z, Lin A, Li C, Liang K, Wang S, Liu Y, Park PK, Qin L, Wei Y, Hawke DH, Hung MC, Lin C, Yang L. IncRNA directs cooperative epigenetic regulation downstream of chemokine signals. Cell. 2014; 159:1110-25. https://doi. org/10.1016/j.cell.2014.10.013.
217. Niknafs YS, Han S, Ma T, Speers C, Zhang C, WilderRomans K, Iyer MK, Pitchiaya S, Malik R, Hosono Y, Prensner JR, Poliakov A, Singhal U, et al. The lncRNA landscape of breast cancer reveals a role for DSCAM-AS1 in breast cancer progression. Nat Commun. 2016; 7:12791. https://doi.org/10.1038/ncomms12791.

218. Miano V, Ferrero G, Reineri S, Caizzi L, Annaratone L, Ricci L, Cutrupi S, Castellano I, Cordero F, De Bortoli M. Luminal long non-coding RNAs regulated by estrogen receptor alpha in a ligand-independent manner show functional roles in breast cancer. Oncotarget. 2016; 7:3201-16. https://doi. org/10.18632/oncotarget.6420.

219. Lin A, Li C, Xing Z, Hu Q, Liang K, Han L, Wang C, Hawke DH, Wang S, Zhang Y, Wei Y, Ma G, Park PK, et al. The LINK-A lncRNA activates normoxic HIF1 $\alpha$ signalling in triple-negative breast cancer. Nat Cell Biol. 2016; 18:213-24. https://doi.org/10.1038/ncb3295.

220. Yue M, Charles Richard JL, Yamada N, Ogawa A, Ogawa Y. Quick fluorescent in situ hybridization protocol for Xist RNA combined with immunofluorescence of histone modification in X-chromosome inactivation. J Vis Exp. 2014; e52053:e52053. https://doi.org/10.3791/52053.

221. Chaumeil J, Augui S, Chow JC, Heard E. Combined immunofluorescence, RNA fluorescent in situ hybridization, and DNA fluorescent in situ hybridization to study chromatin changes, transcriptional activity, nuclear organization, and X-chromosome inactivation. Methods Mol Biol. 2008; 463:297-308. https://doi. org/10.1007/978-1-59745-406-3_18.

222. Gagnon KT, Li L, Chu Y, Janowski BA, Corey DR. RNAi factors are present and active in human cell nuclei. Cell Reports. 2014; 6:211-21. https://doi.org/10.1016/j. celrep.2013.12.013.

223. Gagnon KT, Li L, Janowski BA, Corey DR. Analysis of nuclear RNA interference in human cells by subcellular fractionation and Argonaute loading. Nat Protoc. 2014; 9:2045-60. https://doi.org/10.1038/nprot.2014.135.

224. Dowdy SF. Overcoming cellular barriers for RNA therapeutics. Nat Biotechnol. 2017; 35:222-29. https://doi. org/10.1038/nbt.3802.

225. Lee J, Gollahon L. Nek2-targeted ASO or siRNA pretreatment enhances anticancer drug sensitivity in triple negative breast cancer cells. Int J Oncol. 2013; 42:839-47. https://doi.org/10.3892/ijo.2013.1788.

226. Leucci E, Vendramin R, Spinazzi M, Laurette P, Fiers M, Wouters J, Radaelli E, Eyckerman S, Leonelli C, Vanderheyden K, Rogiers A, Hermans E, Baatsen P, et al. Melanoma addiction to the long non-coding RNA SAMMSON. Nature. 2016; 531:518-22. https://doi. org/10.1038/nature17161.

227. Meng L, Ward AJ, Chun S, Bennett CF, Beaudet AL, Rigo F. Towards a therapy for Angelman syndrome by targeting a long non-coding RNA. Nature. 2015; 518:409-12. https:// doi.org/10.1038/nature13975. 
228. Salameh A, Lee AK, Cardó-Vila M, Nunes DN, Efstathiou E, Staquicini FI, Dobroff AS, Marchiò S, Navone NM, Hosoya H, Lauer RC, Wen S, Salmeron CC, et al. PRUNE2 is a human prostate cancer suppressor regulated by the intronic long noncoding RNA PCA3. Proc Natl Acad Sci USA. 2015; 112:8403-08. https://doi.org/10.1073/pnas.1507882112.

229. Redis RS, Sieuwerts AM, Look MP, Tudoran O, Ivan C, Spizzo R, Zhang X, de Weerd V, Shimizu M, Ling H, Buiga R, Pop V, Irimie A, et al. CCAT2, a novel long noncoding RNA in breast cancer: expression study and clinical correlations. Oncotarget. 2013; 4:1748-62. https://doi. org/10.18632/oncotarget.1292.

230. Pickard MR, Williams GT. Regulation of apoptosis by long non-coding RNA GAS5 in breast cancer cells: implications for chemotherapy. Breast Cancer Res Treat. 2014; 145:359 70. https://doi.org/10.1007/s10549-014-2974-y.

231. Xia Y, Xiao X, Deng X, Zhang F, Zhang X, Hu Q, Sheng W. Targeting long non-coding RNAASBEL with oligonucleotide antagonist for breast cancer therapy. Biochem Biophys Res Commun. 2017; 489:386-92. https://doi.org/10.1016/j. bbrc.2017.05.136.

232. Su X, Malouf GG, Chen Y, Zhang J, Yao H, Valero V, Weinstein JN, Spano JP, Meric-Bernstam F, Khayat D, Esteva FJ. Comprehensive analysis of long non-coding RNAs in human breast cancer clinical subtypes. Oncotarget. 2014; 5:9864-76. https://doi.org/10.18632/oncotarget.2454.

233. Meng J, Li P, Zhang Q, Yang Z, Fu S. A four-long noncoding RNA signature in predicting breast cancer survival. J Exp Clin Cancer Res. 2014; 33:84. https://doi.org/10.1186/ s13046-014-0084-7.

234. Xu N, Chen F, Wang F, Lu X, Wang X, Lv M, Lu C. Clinical significance of high expression of circulating serum lncRNA RP11-445H22.4 in breast cancer patients: a Chinese population-based study. Tumour Biol. 2015; 36:7659-65. https://doi.org/10.1007/s13277-015-3469-0.

235. Zhao W, Luo J, Jiao S. Comprehensive characterization of cancer subtype associated long non-coding RNAs and their clinical implications. Sci Rep. 2014; 4:6591. https://doi. org/10.1038/srep06591.

236. Thomassen M, Tan Q, Kruse TA. Gene expression metaanalysis identifies metastatic pathways and transcription factors in breast cancer. BMC Cancer. 2008; 8:394. https:// doi.org/10.1186/1471-2407-8-394.

237. Shen Q, Brown PH. Novel agents for the prevention of breast cancer: targeting transcription factors and signal transduction pathways. J Mammary Gland Biol Neoplasia. 2003; 8:45-73. https://doi.org/10.1023/A:1025783221557.

238. Raguz S, Yagüe E. Resistance to chemotherapy: new treatments and novel insights into an old problem. $\mathrm{Br}$ J Cancer. 2008; 99:387-91. https://doi.org/10.1038/ sj.bjc. 6604510 .

239. Martin HL, Smith L, Tomlinson DC. Multidrug-resistant breast cancer: current perspectives. Breast Cancer (Dove Med Press). 2014;6:1-13. https://doi.org/10.2147/BCTT.S37638.
240. Broxterman HJ, Gotink KJ, Verheul HM. Understanding the causes of multidrug resistance in cancer: a comparison of doxorubicin and sunitinib. Drug Resist Updat. 2009; 12:114 26. https://doi.org/10.1016/j.drup.2009.07.001.

241. Szakács G, Paterson JK, Ludwig JA, Booth-Genthe C, Gottesman MM. Targeting multidrug resistance in cancer. Nat Rev Drug Discov. 2006; 5:219-34. https://doi.org/10.1038/ nrd1984.

242. Persidis A. Cancer multidrug resistance. Nat Biotechnol. 1999; 17:94-95. https://doi.org/10.1038/5289.

243. Schouten PC, Vollebergh MA, Opdam M, Jonkers M, Loden M, Wesseling J, Hauptmann M, Linn SC. High XIST and Low 53BP1 Expression Predict Poor Outcome after HighDose Alkylating Chemotherapy in Patients with a BRCA1like Breast Cancer. Mol Cancer Ther. 2016; 15:190-98. https://doi.org/10.1158/1535-7163.MCT-15-0470.

244. Miquel-Cases A, Retèl VP, van Harten WH, Steuten LM. Decisions on Further Research for Predictive Biomarkers of High-Dose Alkylating Chemotherapy in Triple-Negative Breast Cancer: A Value of Information Analysis. Value Health. 2016; 19:419-30. https://doi.org/10.1016/j. jval.2016.01.015.

245. Salvador MA, Wicinski J, Cabaud O, Toiron Y, Finetti P, Josselin E, Lelièvre H, Kraus-Berthier L, Depil S, Bertucci F, Collette Y, Birnbaum D, Charafe-Jauffret E, Ginestier C. The histone deacetylase inhibitor abexinostat induces cancer stem cells differentiation in breast cancer with low Xist expression. Clin Cancer Res. 2013; 19:6520-31. https://doi. org/10.1158/1078-0432.CCR-13-0877.

246. Rottenberg S, Vollebergh MA, de Hoon B, de Ronde J, Schouten PC, Kersbergen A, Zander SA, Pajic M, Jaspers JE, Jonkers M, Lodén M, Sol W, van der Burg E, et al. Impact of intertumoral heterogeneity on predicting chemotherapy response of BRCA1-deficient mammary tumors. Cancer Res. 2012; 72:2350-61. https://doi.org/10.1158/0008-5472. CAN-11-4201.

247. Huang YS, Chang CC, Lee SS, Jou YS, Shih HM. Xist reduction in breast cancer upregulates AKT phosphorylation via HDAC3-mediated repression of PHLPP1 expression. Oncotarget. 2016; 7:43256-66. https://doi.org/10.18632/ oncotarget.9673.

248. Zhang Z, Weaver DL, Olsen D, deKay J, Peng Z, Ashikaga T, Evans MF. Long non-coding RNA chromogenic in situ hybridisation signal pattern correlation with breast tumour pathology. J Clin Pathol. 2016; 69:76-81. https://doi. org/10.1136/jclinpath-2015-203275.

249. Koirala P, Huang J, Ho TT, Wu F, Ding X, Mo YY. LncRNA AK023948 is a positive regulator of AKT. Nat Commun. 2017; 8:14422. https://doi.org/10.1038/ncomms14422.

250. He K, Wang P. Unregulated long non-coding RNA-AK058003 promotes the proliferation, invasion and metastasis of breast cancer by regulating the expression levels of the $\gamma$-synuclein gene. Exp Ther Med. 2015; 9:172732. https://doi.org/10.3892/etm.2015.2323. 
251. Chi Y, Huang S, Yuan L, Liu M, Huang N, Zhou S, Zhou $\mathrm{B}, \mathrm{Wu}$ J. Role of BC040587 as a predictor of poor outcome in breast cancer. Cancer Cell Int. 2014; 14:123. https://doi. org/10.1186/s12935-014-0123-7.

252. Singh R, Gupta SC, Peng WX, Zhou N, Pochampally R, Atfi A, Watabe K, Lu Z, Mo YY. Regulation of alternative splicing of Bcl-x by BC200 contributes to breast cancer pathogenesis. Cell Death Dis. 2016; 7:e2262. https://doi. org/10.1038/cddis.2016.168.

253. Iacoangeli A, Lin Y, Morley EJ, Muslimov IA, Bianchi R, Reilly J, Weedon J, Diallo R, Böcker W, Tiedge H. BC200 RNA in invasive and preinvasive breast cancer. Carcinogenesis. 2004; 25:2125-33. https://doi.org/10.1093/ carcin/bgh228.

254. Yang F, Xue X, Bi J, Zheng L, Zhi K, Gu Y, Fang G. Long noncoding RNA CCAT1, which could be activated by c-Myc, promotes the progression of gastric carcinoma. J Cancer Res Clin Oncol. 2013; 139:437-45. https://doi.org/10.1007/ s00432-012-1324-X.

255. Xu J, Chen Y, Olopade OI. MYC and Breast Cancer. Genes Cancer. 2010; 1:629-40. https://doi. org/10.1177/1947601910378691.

256. Dang CV, O’Donnell KA, Zeller KI, Nguyen T, Osthus $\mathrm{RC}$, Li F. The c-Myc target gene network. Semin Cancer Biol. 2006; 16:253-64. https://doi.org/10.1016/j. semcancer.2006.07.014.

257. Zhang XF, Liu T, Li Y, Li S. Overexpression of long noncoding RNA CCAT1 is a novel biomarker of poor prognosis in patients with breast cancer. Int J Clin Exp Pathol. 2015; 8:9440-45.

258. Cai Y, He J, Zhang D. Long noncoding RNA CCAT2 promotes breast tumor growth by regulating the Wnt signaling pathway. Onco Targets Ther. 2015; 8:2657-64. https://doi.org/10.2147/OTT.S90485.

259. Yang W, Du WW, Li X, Yee AJ, Yang BB. Foxo3 activity promoted by non-coding effects of circular RNA and Foxo3 pseudogene in the inhibition of tumor growth and angiogenesis. Oncogene. 2016; 35:3919-31. https://doi. org/10.1038/onc.2015.460.

260. Du WW, Yang W, Liu E, Yang Z, Dhaliwal P, Yang BB. Foxo3 circular RNA retards cell cycle progression via forming ternary complexes with p21 and CDK2. Nucleic Acids Res. 2016; 44:2846-58. https://doi.org/10.1093/nar/ gkw027.

261. Liang HF, Zhang XZ, Liu BG, Jia GT, Li WL. Circular RNA circ-ABCB10 promotes breast cancer proliferation and progression through sponging miR-1271. Am J Cancer Res. 2017; 7:1566-76.

262. Betts JA, Moradi Marjaneh M, Al-Ejeh F, Lim YC, Shi W, Sivakumaran H, Tropée R, Patch AM, Clark MB, Bartonicek N, Wiegmans AP, Hillman KM, Kaufmann S, et al. Long Noncoding RNAs CUPID1 and CUPID2 Mediate Breast Cancer Risk at 11q13 by Modulating the Response to DNA
Damage. Am J Hum Genet. 2017; 101:255-66. https://doi. org/10.1016/j.ajhg.2017.07.007.

263. Van Grembergen O, Bizet M, de Bony EJ, Calonne E, Putmans P, Brohée S, Olsen C, Guo M, Bontempi G, Sotiriou C, Defrance M, Fuks F. Portraying breast cancers with long noncoding RNAs. Sci Adv. 2016; 2:e1600220-1600220. https://doi.org/10.1126/sciadv.1600220.

264. Sha S, Yuan D, Liu Y, Han B, Zhong N. Targeting long non-coding RNA DANCR inhibits triple negative breast cancer progression. Biol Open. 2017; 6:1310-16. https://doi. org/10.1242/bio.023135.

265. Xu S, Wang P, You Z, Meng H, Mu G, Bai X, Zhang G, Zhang J, Pang D. The long non-coding RNA EPB41L4A-AS2 inhibits tumor proliferation and is associated with favorable prognoses in breast cancer and other solid tumors. Oncotarget. 2016; 7:20704-17. https://doi.org/10.18632/ oncotarget.8007.

266. Yang F, Liu YH, Dong SY, Ma RM, Bhandari A, Zhang XH, Wang OC. A novel long non-coding RNA FGF14-AS2 is correlated with progression and prognosis in breast cancer. Biochem Biophys Res Commun. 2016; 470:479-83. https:// doi.org/10.1016/j.bbrc.2016.01.147.

267. Pickard MR, Williams GT. Molecular and Cellular Mechanisms of Action of Tumour Suppressor GAS5 LncRNA. Genes (Basel). 2015; 6:484-99. https://doi. org/10.3390/genes6030484.

268. Mourtada-Maarabouni M, Pickard MR, Hedge VL, Farzaneh F, Williams GT. GAS5, a non-protein-coding RNA, controls apoptosis and is downregulated in breast cancer. Oncogene. 2009; 28:195-208. https://doi.org/10.1038/onc.2008.373.

269. Pickard MR, Williams GT. The hormone response element mimic sequence of GAS5 lncRNA is sufficient to induce apoptosis in breast cancer cells. Oncotarget. 2016; 7:10104 16. https://doi.org/10.18632/oncotarget.7173.

270. Li W, Zhai L, Wang H, Liu C, Zhang J, Chen W, Wei Q. Downregulation of LncRNA GAS5 causes trastuzumab resistance in breast cancer. Oncotarget. 2016; 7:27778-86. https://doi.org/10.18632/oncotarget.8413.

271. Matouk IJ, Halle D, Raveh E, Gilon M, Sorin V, Hochberg A. The role of the oncofetal H19 lncRNA in tumor metastasis: orchestrating the EMT-MET decision. Oncotarget. 2016; 7:3748-65. https://doi.org/10.18632/oncotarget.6387.

272. Matouk IJ, Raveh E, Abu-lail R, Mezan S, Gilon M, Gershtain E, Birman T, Gallula J, Schneider T, Barkali M, Richler C, Fellig Y, Sorin V, et al. Oncofetal H19 RNA promotes tumor metastasis. Biochim Biophys Acta - Mol. Cell Res. 2014; 1843:1414-26. https://doi.org/10.1016/j. bbamcr.2014.03.023.

273. Kallen AN, Zhou XB, Xu J, Qiao C, Ma J, Yan L, Lu L, Liu C, Yi JS, Zhang H, Min W, Bennett AM, Gregory RI, et al. The imprinted H19 lncRNA antagonizes let-7 microRNAs. Mol Cell. 2013; 52:101-12. https://doi.org/10.1016/j. molcel.2013.08.027. 
274. Barsyte-Lovejoy D, Lau SK, Boutros PC, Khosravi F, Jurisica I, Andrulis IL, Tsao MS, Penn LZ. The c-Myc oncogene directly induces the H19 noncoding RNA by allele-specific binding to potentiate tumorigenesis. Cancer Res. 2006; 66:5330-37. https://doi.org/10.1158/0008-5472. CAN-06-0037.

275. Cai X, Cullen BR. The imprinted H19 noncoding RNA is a primary microRNA precursor. RNA. 2007; 13:313-16. https://doi.org/10.1261/rna.351707.

276. Lottin S, Adriaenssens E, Dupressoir T, Berteaux N, Montpellier C, Coll J, Dugimont T, Curgy JJ. Overexpression of an ectopic $\mathrm{H} 19$ gene enhances the tumorigenic properties of breast cancer cells. Carcinogenesis. 2002; 23:1885-95. https://doi.org/10.1093/carcin/23.11.1885.

277. Xue X, Yang YA, Zhang A, Fong KW, Kim J, Song B, Li S, Zhao JC, Yu J. LncRNA HOTAIR enhances ER signaling and confers tamoxifen resistance in breast cancer. Oncogene. 2016; 35:2746-55. https://doi.org/10.1038/onc.2015.340.

278. Hajjari M, Salavaty A. HOTAIR: an oncogenic long noncoding RNA in different cancers. Cancer Biol Med. 2015; 12:1-9. https://doi.org/10.7497/j.issn.2095-3941.2015.0006.

279. Tao S, He H, Chen Q, Yue W. GPER mediated estradiol reduces miR-148a to promote HLA-G expression in breast cancer. Biochem Biophys Res Commun. 2014; 451:74-78. https://doi.org/10.1016/j.bbrc.2014.07.073.

280. Pádua Alves C, Fonseca AS, Muys BR, de Barros E Lima Bueno R, Bürger MC, de Souza JE, Valente V, Zago MA, Silva WA Jr. Brief report: the lincRNA Hotair is required for epithelial-to-mesenchymal transition and stemness maintenance of cancer cell lines. Stem Cells. 2013; 31:282732. https://doi.org/10.1002/stem.1547.

281. Zhang H, Cai K, Wang J, Wang X, Cheng K, Shi F, Jiang L, Zhang Y, Dou J. MiR-7, inhibited indirectly by lincRNA HOTAIR, directly inhibits SETDB1 and reverses the EMT of breast cancer stem cells by downregulating the STAT3 pathway. Stem Cells. 2014; 32:2858-68. https://doi. org/10.1002/stem.1795.

282. Zhang X, Lian Z, Padden C, Gerstein MB, Rozowsky J, Snyder M, Gingeras TR, Kapranov P, Weissman SM, Newburger PE. A myelopoiesis-associated regulatory intergenic noncoding RNA transcript within the human HOXA cluster. Blood. 2009; 113:2526-34. https://doi. org/10.1182/blood-2008-06-162164.

283. Zhang X, Weissman SM, Newburger PE. Long intergenic non-coding RNA HOTAIRM1 regulates cell cycle progression during myeloid maturation in NB4 human promyelocytic leukemia cells. RNA Biol. 2014; 11:777-87. https://doi.org/10.4161/rna.28828.

284. Shi F, Xiao F, Ding P, Qin H, Huang R. Long Noncoding RNA Highly Up-regulated in Liver Cancer Predicts Unfavorable Outcome and Regulates Metastasis by MMPs in Triple-negative Breast Cancer. Arch Med Res. 2017; 47:44653. https://doi.org/10.1016/j.arcmed.2016.11.001.
285. Salameh A, Fan X, Choi BK, Zhang S, Zhang N, An Z. HER3 and LINC00052 interplay promotes tumor growth in breast cancer. Oncotarget. 2017; 8:6526-39. https://doi. org/10.18632/oncotarget.14313.

286. Hou P, Zhao Y, Li Z, Yao R, Ma M, Gao Y, Zhao L, Zhang Y, Huang B, Lu J. LincRNA-ROR induces epithelial-tomesenchymal transition and contributes to breast cancer tumorigenesis and metastasis. Cell Death Dis. 2014; 5:e1287. https://doi.org/10.1038/cddis.2014.249.

287. Eades G, Wolfson B, Zhang Y, Li Q, Yao Y, Zhou Q. lincRNA-RoR and miR-145 regulate invasion in triplenegative breast cancer via targeting ARF6. Mol Cancer Res. 2015; 13:330-38. https://doi.org/10.1158/1541-7786. MCR-14-0251.

288. Sun M, Liu XH, Wang KM, Nie FQ, Kong R, Yang JS, Xia R, Xu TP, Jin FY, Liu ZJ, Chen JF, Zhang EB, De W, Wang ZX. Downregulation of BRAF activated non-coding RNA is associated with poor prognosis for non-small cell lung cancer and promotes metastasis by affecting epithelialmesenchymal transition. Mol Cancer. 2014; 13:68. https:// doi.org/10.1186/1476-4598-13-68.

289. Zhou M, Hou Y, Yang G, Zhang H, Tu G, Du YE, Wen S, Xu L, Tang X, Tang S, Yang L, Cui X, Liu M. LncRNA-Hh Strengthen Cancer Stem Cells Generation in Twist-Positive Breast Cancer via Activation of Hedgehog Signaling Pathway. Stem Cells. 2016; 34:55-66. https://doi. org/10.1002/stem.2219.

290. Su JC, Hu XF. Long non coding RNA HOXA11 AS promotes cell proliferation and metastasis in human breast cancer. Mol Med Rep. 2017; 16:4887-94. https://doi.org/10.3892/ mmr.2017.7163.

291. Wan G, Hu X, Liu Y, Han C, Sood AK, Calin GA, Zhang $\mathrm{X}, \mathrm{Lu} \mathrm{X}$. A novel non-coding RNA lncRNA-JADE connects DNA damage signalling to histone $\mathrm{H} 4$ acetylation. EMBO J. 2013; 32:2833-47. https://doi.org/10.1038/emboj.2013.221.

292. Zhang Y, He Q, Hu Z, Feng Y, Fan L, Tang Z, Yuan J, Shan W, Li C, Hu X, Tanyi JL, Fan Y, Huang Q, et al. Long noncoding RNA LINP1 regulates repair of DNA doublestrand breaks in triple-negative breast cancer. Nat Struct Mol Biol. 2016; 23:522-30. https://doi.org/10.1038/nsmb.3211.

293. Shi Y, Lu J, Zhou J, Tan X, He Y, Ding J, Tian Y, Wang L, Wang K. Long non-coding RNA Loc554202 regulates proliferation and migration in breast cancer cells. Biochem Biophys Res Commun. 2014; 446:448-53. https://doi. org/10.1016/j.bbrc.2014.02.144.

294. Augoff K, McCue B, Plow EF, Sossey-Alaoui K. miR-31 and its host gene lncRNA LOC554202 are regulated by promoter hypermethylation in triple-negative breast cancer. Mol Cancer. 2012; 11:5. https://doi.org/10.1186/1476-4598-11-5.

295. Jiang M, Huang O, Xie Z, Wu S, Zhang X, Shen A, Liu H, Chen X, Wu J, Lou Y, Mao Y, Sun K, Hu S, et al. A novel long non-coding RNA-ARA: adriamycin resistanceassociated. Biochem Pharmacol. 2014; 87:254-83. https:// doi.org/10.1016/j.bcp.2013.10.020. 
296. Silva JM, Boczek NJ, Berres MW, Ma X, Smith DI. LSINCT5 is over expressed in breast and ovarian cancer and affects cellular proliferation. RNA Biol. 2011; 8:496-505. https://doi.org/10.4161/rna.8.3.14800.

297. Zhao Z, Chen C, Liu Y, Wu C. 17ß-Estradiol treatment inhibits breast cell proliferation, migration and invasion by decreasing MALAT-1 RNA level. Biochem Biophys Res Commun. 2014; 445:388-93. https://doi.org/10.1016/j. bbrc.2014.02.006.

298. Schmidt LH, Görlich D, Spieker T, Rohde C, Schuler M, Mohr M, Humberg J, Sauer T, Thoenissen NH, Huge A, Voss R, Marra A, Faldum A, et al. Prognostic impact of Bcl-2 depends on tumor histology and expression of MALAT-1 lncRNA in non-small-cell lung cancer. J Thorac Oncol. 2014; 9:1294-304. https://doi.org/10.1097/ JTO.0000000000000243.

299. Xu S, Sui S, Zhang J, Bai N, Shi Q, Zhang G, Gao S, You Z, Zhan C, Liu F, Pang D. Downregulation of long noncoding RNA MALAT1 induces epithelial-to-mesenchymal transition via the PI3K-AKT pathway in breast cancer. Int J Clin Exp Pathol. 2015; 8:4881-91.

300. Chou J, Wang B, Zheng T, Li X, Zheng L, Hu J, Zhang Y, Xing Y, Xi T. MALAT1 induced migration and invasion of human breast cancer cells by competitively binding miR-1 with cdc42. Biochem Biophys Res Commun. 2016; 472:26269. https://doi.org/10.1016/j.bbrc.2016.02.102.

301. Jadaliha M, Zong X, Malakar P, Ray T, Singh DK, Freier SM, Jensen T, Prasanth SG, Karni R, Ray PS, Prasanth KV. Functional and prognostic significance of long non-coding RNA MALAT1 as a metastasis driver in ER negative lymph node negative breast cancer. Oncotarget. 2016; 7:40418-36. https://doi.org/10.18632/oncotarget.9622.

302. Feng T, Shao F, Wu Q, Zhang X, Xu D, Qian K, Xie Y, Wang S, Xu N, Wang Y, Qi C. miR-124 downregulation leads to breast cancer progression via LncRNA-MALAT1 regulation and CDK4/E2F1 signal activation. Oncotarget. 2016; 7:16205-16. https://doi.org/10.18632/oncotarget.7578.

303. Miao Y, Fan R, Chen L, Qian H. Clinical significance of long non-coding RNA MALAT1 expression in tissue and serum of breast cancer. Ann Clin Lab Sci. 2016; 46:418-24.

304. Diermeier SD, Chang KC, Freier SM, Song J, El Demerdash O, Krasnitz A, Rigo F, Bennett CF, Spector DL. Mammary Tumor-Associated RNAs Impact Tumor Cell Proliferation, Invasion, and Migration. Cell Reports. 2016; 17:261-74. https://doi.org/10.1016/j.celrep.2016.08.081.

305. Mondal T, Subhash S, Vaid R, Enroth S, Uday S, Reinius B, Mitra S, Mohammed A, James AR, Hoberg E, Moustakas A, Gyllensten U, Jones SJ, et al. MEG3 long noncoding RNA regulates the TGF- $\beta$ pathway genes through formation of RNA-DNA triplex structures. Nat Commun. 2015; 6:7743. https://doi.org/10.1038/ncomms8743.

306. Zhou Y, Zhang X, Klibanski A. MEG3 noncoding RNA: a tumor suppressor. J Mol Endocrinol. 2012; 48:R45-53. https://doi.org/10.1530/JME-12-0008.
307. Lei B, Xu SP, Liang XS, Li YW, Zhang JF, Zhang GQ, Pang D. Long non-coding RNA MVIH is associated with poor prognosis and malignant biological behavior in breast cancer. Tumour Biol. 2016; 37:5257-64. https://doi.org/10.1007/ s13277-015-4360-8.

308. Ke H, Zhao L, Feng X, Xu H, Zou L, Yang Q, Su X, Peng L, Jiao B. NEAT1 is required for survival of breast cancer cells through FUS and miR-548. Gene Regul Syst Bio. 2016; 10:11-17. https://doi.org/10.4137/GRSB.S29414.

309. Liu B, Sun L, Liu Q, Gong C, Yao Y, Lv X, Lin L, Yao H, Su F, Li D, Zeng M, Song E. A cytoplasmic NF- $\kappa$ B interacting long noncoding RNA blocks $\mathrm{I} \kappa \mathrm{B}$ phosphorylation and suppresses breast cancer metastasis. Cancer Cell. 2015; 27:370-81. https://doi.org/10.1016/j.ccell.2015.02.004.

310. Shi Y, Li J, Liu Y, Ding J, Fan Y, Tian Y, Wang L, Lian Y, Wang K, Shu Y. The long noncoding RNA SPRY4-IT1 increases the proliferation of human breast cancer cells by upregulating ZNF703 expression. Mol Cancer. 2015; 14:51. https://doi.org/10.1186/s12943-015-0318-0.

311. Zong X, Nakagawa S, Freier SM, Fei J, Ha T, Prasanth SG, Prasanth KV. Natural antisense RNA promotes 3' end processing and maturation of MALAT1 lncRNA. Nucleic Acids Res. 2016; 44:2898-908. https://doi.org/10.1093/nar/ gkw047.

312. Marini A, Lena AM, Panatta E, Ivan C, Han L, Liang H, Annicchiarico-Petruzzelli M, Di Daniele N, Calin GA, Candi E, Melino G. Ultraconserved long non-coding RNA uc.63 in breast cancer. Oncotarget. 2017; 8:35669-35680.https://doi. org/10.18632/oncotarget.10572.

313. Ferdin J, Nishida N, Wu X, Nicoloso MS, Shah MY, Devlin C, Ling H, Shimizu M, Kumar K, Cortez MA, Ferracin M, Bi Y, Yang D, et al. HINCUTs in cancer: hypoxia-induced noncoding ultraconserved transcripts. Cell Death Differ. 2013; 20:1675-87. https://doi.org/10.1038/cdd.2013.119 PMID:24037088.

314. Tuo YL, Li XM, Luo J. Long noncoding RNA UCA1 modulates breast cancer cell growth and apoptosis through decreasing tumor suppressive miR-143. Eur Rev Med Pharmacol Sci. 2015; 19:3403-11. PMID:26439035.

315. Huang J, Zhou N, Watabe K, Lu Z, Wu F, Xu M, Mo YY. Long non-coding RNA UCA1 promotes breast tumor growth by suppression of p27 (Kip1). Cell Death Dis. 2014; 5:e1008. https://doi.org/10.1038/cddis.2013.541 PMID:24457952.

316. Liu H, Wang G, Yang L, Qu J, Yang Z, Zhou X. Knockdown of Long Non-Coding RNA UCA1 Increases the Tamoxifen Sensitivity of Breast Cancer Cells through Inhibition of Wnt/ $\beta$-Catenin Pathway. PLoS One. 2016; 11:e0168406. http://dx.doi.org/10.1371\%2Fjournal. pone. 0168406 .

317. Shi SJ, Wang LJ, Yu B, Li YH, Jin Y, Bai XZ. LncRNA-ATB promotes trastuzumab resistance and invasion-metastasis cascade in breast cancer. Oncotarget. 2015; 6:11652-63. https://doi.org/10.18632/oncotarget.3457.

318. Godinho MF, Wulfkuhle JD, Look MP, Sieuwerts AM, Sleijfer S, Foekens JA, Petricoin EF 3rd, Dorssers LC, van 
Agthoven T. BCAR4 induces antioestrogen resistance but sensitises breast cancer to lapatinib. Br J Cancer. 2012; 107:947-55. https://doi.org/10.1038/bjc.2012.351.

319. Jiang YZ, Liu YR, Xu XE, Jin X, Hu X, Yu KD, Shao ZM. Transcriptome Analysis of Triple-Negative Breast Cancer Reveals an Integrated mRNA-lncRNA Signature with Predictive and Prognostic Value. Cancer Res. 2016; 76:210514. https://doi.org/10.1158/0008-5472.CAN-15-3284.

320. Wu C, Luo J. Long Non-Coding RNA (IncRNA) Urothelial Carcinoma-Associated 1 (UCA1) Enhances Tamoxifen Resistance in Breast Cancer Cells via Inhibiting mTOR Signaling Pathway. Med Sci Monit. 2016; 22:3860-67. https://doi.org/10.12659/MSM.900689.

321. Li X, Wu Y, Liu A, Tang X. Long non-coding RNA UCA1 enhances tamoxifen resistance in breast cancer cells through a miR-18a-HIF1 $\alpha$ feedback regulatory loop. Tumour Biol. 2016; 37:14733-43. https://doi.org/10.1007/s13277-0165348-8 PMID:27629141.

322. Li Y, Jiang B, Zhu H, Qu X, Zhao L, Tan Y, Jiang Y, Liao $\mathrm{M}, \mathrm{Wu} \mathrm{X}$. Inhibition of long non-coding RNA ROR reverses resistance to Tamoxifen by inducing autophagy in breast cancer. Tumour Biol. 2017; 39:1010428317705790. https:// doi.org/10.1177/1010428317705790.
323. Zhang HY, Liang F, Zhang JW, Wang F, Wang L, Kang XG. Effects of long noncoding RNA-ROR on tamoxifen resistance of breast cancer cells by regulating microRNA-205. Cancer Chemother Pharmacol. 2017; 79:327-37. https://doi. org/10.1007/s00280-016-3208-2.

324. Si X, Zang R, Zhang E, Liu Y, Shi X, Zhang E, Shao L, Li A, Yang N, Han X, Pan B, Zhang Z, Sun L, Sun Y. LncRNA H19 confers chemoresistance in ER $\alpha$-positive breast cancer through epigenetic silencing of the pro-apoptotic gene BIK. Oncotarget. 2016; 7:81452-62. https://doi.org/10.18632/ oncotarget.13263.

325. Cai Y, He J, Zhang D. Mol Biol. 2016; 50:821-27. Suppression of long non-coding RNA CCAT2 improves tamoxifen-resistant breast cancer cells' response to tamoxifen. https://doi.org/10.7868/S0026898416030046.

326. Wang YL, Overstreet AM, Chen MS, Wang J, Zhao HJ, Ho PC, Smith M, Wang SC. Combined inhibition of EGFR and c-ABL suppresses the growth of triple-negative breast cancer growth through inhibition of HOTAIR. Oncotarget. 2015; 6:11150-61. https://doi.org/10.18632/oncotarget.3441. 